\title{
Intellectual structure of the entrepreneurship field: a tale based on three core journals
}

\author{
Aurora A.C. Teixeira ${ }^{1,2,3}$, Elsa Ferreira $^{4}$ \\ ${ }^{1}$ CEF.UP, Faculdade de Economia, University of Porto, Portugal \\ ${ }^{2}$ INESC Porto, Portugal \\ ${ }^{3}$ OBEGEF, Portugal \\ ateixeira@fep.up.pt \\ ${ }^{4}$ Faculdade de Ciências da Nutrição e Alimentação, Universidade do Porto, Portugal \\ elsa.ferreira@fcna.up.pt
}

\begin{abstract}
Underlying the scientific structure of a field is the network of informal communication linkages established among the most influential scholars within the area. These groups of mutually interacting and prolific scientists who exchange knowledge through communication channels are named "invisible colleges". In this study, we perform a two-stage analysis to identify invisible colleges in the field of entrepreneurship using three core journals: Entrepreneurship Theory and Practice (ETP); Journal of Business Venturing (JBV), and Small Business Economics (SBE). Using bibliometrics, a in depth analysis was conducted on the most influential authors, their professional affiliation and educational training, in order to map the informal links between the most-cited authors. Based on over 90 thousand citations from these 3 journals two invisible colleges emerged: ETP and JBV have similar intellectual groundings, targeting especially corporate and entrepreneurship venturing, while SBE gives emphasis to more economics-oriented research, namely innovation, growth and policy, and industrial dynamics.
\end{abstract}

Keywords. Invisible College, Entrepreneurship, Bibliometrics.

\section{Introduction}

Academic research on entrepreneurship has increased over the last few decades, accompanying society's interest in the matter (Landström, 2005; Aldrich, 2012; Shane, 2012; Carlsson et al., 2013). In fact, entrepreneurship research and teaching has been one of the most prominent social sciences in recent years, with jobs with a focus on entrepreneurship and faculty expertise in entrepreneurship continuing to rise (Finkle, 2007; Venkataraman et al., 2012; Gartner, 2013).

The explosion of entrepreneurship scholarship led to the need to measure scientific production (namely through bibliometric and scientometric approaches) in entrepreneurship and to understand the scientific structure of the field, such that several studies have dedicated significant attention to the matter (Cornelius et al., 2006, Grégoire et al., 2006, Schildt et al., 2006; Teixeira, 2011; Landström et al., 2012). Underlying the scientific structure of a field is a network of informal communication linkages among the most influential scholars within that area. These groups of mutually interacting and prolific scientists, who exchange knowledge through communication channels, were named "invisible colleges" (Crane, 1972; McMillan, 2008; Vogel, 2012) and are the focus of our study. In spite of the academic interest in entrepreneurship, research on invisible colleges, per se, are still relatively unexplored (some of the few articles on the subject include Reader and Watkins 
(2006) and Teixeira (2011)).

According to Landström et al. (2012), despite some signs of differentiation, the field of entrepreneurship is increasingly formalized and anchored in a small set of intellectual bases. The signs of fragmentation and specialization, reflected in the emergency of a number of subject specialties, are demonstrated in Teixeira (2011), who following a formal selection procedure to delimit the 'relational environment' of the field of entrepreneurship, analyzes the existence and characterizes the (in)visible college(s) of this field.

The 'invisible colleges' facilitate a process of social diffusion that fuels the growth of scientific specialties (Carey, 2011). This diffusion of ideas operates both through linkages between researchers and published journal articles. The former channel is particularly emphasized in the study of Teixeira (2011). The present paper seeks to complement Teixeira's (2011) contribution by focusing the analysis on three core entrepreneurship journals and thus providing a more in depth, though with lesser scope, perspective of the (potential) invisible colleges in the field. Researchers have long noted the importance of 'invisible colleges' in transmitting knowledge within disciplines. Thus, an analysis of the three core entrepreneurship journals provides valuable insights on how knowledge flows and who are the knowledge gatekeepers in those journals, permitting to uncover potential signs of differentiation and specialization which are likely to be useful for both newcomer and established researchers aiming to publish in this challenging area.

Contrary to Teixeira (2011), who used a statistical delimitation procedure to identify the 7 journals that 'defined' the entrepreneurship field, in the present paper we opted for a more conventional selection procedure based on relevant literature which identifies Entrepreneurship Theory and Practice (ETP); Journal of Business Venturing (JBV) and Small Business Economics (SBE) as core entrepreneurship journals (Katz, and Boal, 2002; Ritzberger, 2008; Stewart and Cotton, 2013). For each journal we collected all the articles published from their inception until the end of 2008. The main unit of analysis for identifying invisible colleges is citations to these articles (Zuccala, 2006; Dos Santos et al., 2011). Given that recent articles (those published in the last 3 years) receive few citations and the citations structure of rather old articles is unlike to change significantly in a three year period (Vieira and Teixeira, 2010), the truncation date we established for gathering citations (February 2009) might be acceptable. However, it is important to remark that the citations structure of articles published in the neighborhood of the the truncation date are likely to be significantly influenced by such a truncation option.

Resorting to Zuccala's (2006) framework, we gathered evidence about the most-cited authors, studies (articles or books) and journals for each of the core journals, enabling us to characterize the intellectual groundings of entrepreneurship, comparing the results for each of the selected journals. We then confirmed the existence of linkages between the most influential (i.e., most-cited) authors, through a all-inclusive study of their affiliations, educational training and research areas. Examining the social ties (or links) that connect influential authors in the field of entrepreneurship is fundamental to understanding the multifaceted nature of invisible colleges, since these are based on the (formal and informal) exchange of scientific knowledge. The combination of evidence gave us empirical support to conclude that there are distinct invisible colleges within the field of entrepreneurship.

The paper is structured as follows. In Section 2 the concept of invisible college is defined and related literature reviewed, including a description of Zuccala's (2006) approach. Section 3 details the bibliometric and scientometric methods, illustrating their main applications in entrepreneurship and other scientific areas; additionally, it describes the data and methodology pursued. The following section analyzes the most-cited authors, studies and journals in each core journal, further performing a 
comprehensive study of the linkages among the most-cited authors. Finally, we draw the main conclusions, pointing out the study's limitations and suggesting paths for future research.

\section{Searching for Invisible Colleges in entrepreneurship scientific research: a literature review}

Back in the 1970s, Price (1971) defined an 'invisible college' as a hierarchical and elitist group of scholars, supported by an expectable inequality and a high level of connection. Influenced by Price's work Crane (1972) advanced with a wide-ranging examination of the invisible college phenomenon and expanded the scope of the concept of informal communication, to include informal discussions, relationships between teachers and students during thesis preparation, and the influence of a scientist's work on another (Teixeira, 2011).

More recently, Zuccala (2006: 155) emphasized the need to understand the multifaceted nature of the invisible college, proposing the following definition:

An invisible college is a set of interacting scholars or scientists who share similar research interests concerning a subject specialty, who often produce publications relevant to this subject and who communicate both formally and informally with one another to work towards important goals in the subject, even though they may belong to geographically distant research affiliates.

The novelty in the definition, as Zuccala (2006) pointed out, is its openness to the possibility of combining different types of analysis - bibliometric, sociometric and qualitative - in the study of invisible colleges, benefiting from their unique contributions.

The majority of the studies which aim to identify the invisible colleges of the respective journals (e.g., McMillan and Casey, 2007; Casey and McMillan, 2008) undertake co-citation analyses. Indeed, co-citation analyses have developed into the main bibliometric technique to explore the intellectual structure of scientific communication (Lievrouw, 1989; Bayer et al., 1990; Gmür, 2003). According to Bellardo (1980: 231), co-citation analysis is founded on the premise that "the greater the number of times that a pair of documents is cited together, the more likely it is that they are related in content". A co-citation occurs when two references or authors are mentioned in the same bibliography and serves as a measurement for the closeness of content (Small, 1973; Garfield et al., 1978; Gmür, 2003). Although there has been some criticism regarding the use of citation and co-citation analysis, as the use of citation links is considered an inadequate representation of communication among researchers (Lievrouw, 1989), their credibility as indicators of scientific communication was vouched for by authors such as Small (1978) and Garfield (1979), and they constitute the grounding for identifying invisible colleges (Gmür, 2003).

Studies in general, as mentioned earlier, define invisible colleges as social processes, based on informal links. However, empirically, 'operational' invisible colleges are treated as structures of scholarship, measured by formal elements such as published documents. Although co-citation analysis is based on formal links, the key issue here is that the invisible colleges measured as such, involve research networks of authors who refer to each other in their documents without being linked by 'formal' organizational ties. Applications of this process encompass distinct areas such as economics (McMillan and Casey, 2007; Casey and McMillan, 2008) and management (McMillan, 2008). Verspagen and Werker (2004) apply a slightly different 
methodology by using a survey to map the intellectual relations between active contributors in the discipline and identified possible social networks, i.e., invisible colleges.

In the scientific area of entrepreneurship, Reader and Watkins (2006) explored the existence of invisible colleges by complementing a co-citation analysis of the field's scientific structure with a questionnaire survey. The authors employed a comprehensive database, created by the Southampton Business School, which includes full coverage of the major niche journals in entrepreneurship, conference proceedings and other major, but not so specific, journals such as those on the Social Sciences Citation Index. The key authors were identified through a process of cross-referencing that reduced a list of 4405 documents initially generated by a keyword search of the word "Entrepreneur\$" within the database. Using author co-citation and factor analysis, the authors try to identify, respectively, groups of entrepreneurship scholars whose work falls into similar areas and the topics that characterize and define the field. The survey allowed them to explore the social and collaborative nature of entrepreneurship research among the leading co-cited authors, unveiled in the first stage of the work. Therefore, the subfields identified in the author co-citation analysis of informal communication links between closely related authors and then validated by the survey, represent the "invisible colleges" to Reader and Watkins (2006).

In spite of the high-quality research dedicated to assessing the intellectual structure of the field of entrepreneurship, namely the presence and nature of scholarly communities that comprise the field, literature specifically focused on the matter of invisible colleges is still rare. The multifaceted nature of this phenomenon, particularly the structure versus social process issue, requires, as Lievrouw (1989) recommended, distinct approaches to the subject in order to provide new insights. Thus, we aim to explore the existence of invisible colleges in the field of entrepreneurship, undertaking a citation analysis of the articles published in three core journals in the area - Entrepreneurship Theory and Practice; Journal Business Venturing and Small Business Economics. For this purpose, and similarly to Teixeira (2011), the methodology proposed by Zuccalla (2006) was used, in order to explore the (widely debatable) concept of 'invisible college'. We argue that although the theory underlying the concept is well developed and relatively consensual, the empirical application of such a concept lags far behind theoretical achievements. Moreover, in our view, there is a need for an objective framework structure which enables, in a more precise manner, the 'measurement' and 'assessment' of invisible colleges.

According to Zuccala's (2006) definition of Invisible Colleges, mentioned earlier, and the corresponding research framework, an invisible college is a consequence of an interrelationship (through formal and informal communication) between three key elements: subject specialty, the social actors and Information Use Environment. The first informs the invisible college of its disciplinary rules and research problems, the second refers to the scientific scholars who understand and agree to the rules and interact with one another to solve problems, and the third and last element, represents the scientific workspace, i.e., the "set of elements that affect the flow and use of information messages into, within, and out of any definable entity" (Taylor, 1986: 3). The social actors, i.e., the most influential authors, make use of the invisible college to support their search of information and sharing patterns (informal communication) and reinforce the invisible college through bibliometric artefacts (formal communication). Therefore, Zuccala (2006: 8) concludes that the invisible college is an organizational structure produced by "the space that intersects the Information Use Environment, the subject specialty and the social actors" (cf., Fig. 1).

Thus, similarly to previous studies (e.g., McMillan, 2008; Casey and McMillan, 2008; 
McMillan and Casey, 2007; Teixeira, 2011; Landström et al., 2012), this work applies a bibliometric analysis in order to obtain empirical evidence from which the development of the field's intellectual bases can be assessed. However, unlike some of these studies which are constrained to a narrow definition of invisible colleges and provide few insights regarding scholars interrelatedness through informal channels, but in line with the approach followed by Teixeira (2011), we complement the study of the most-cited authors, articles/books and journals, with an analysis of the linkages between the most influential (i.e., most-cited) authors, based on their educational affiliation, professional affiliation and research area.

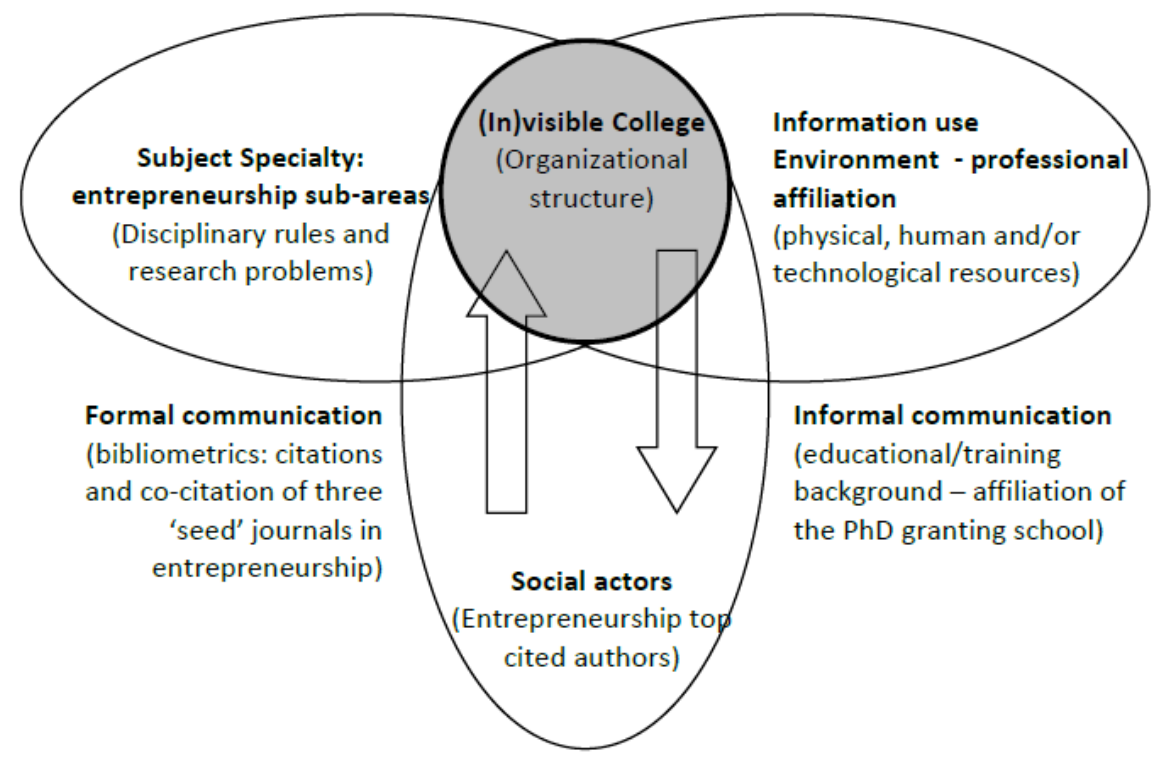

Fig. 1. Conceptual model to analyze the structure of an invisible college in entrepreneurship. Source: In Teixeira (2011: 10), and adapted from Zuccala (2006: 156)

The use of three core journals, instead of only a single journal analysis (e.g., McMillan, 2008), permits determining whether there are distinct invisible colleges within the field of entrepreneurship according to the core journal considered. By circumscribing the study to three niche journals but including all articles available until February 2009, we ensure a wide-ranging analysis that preserves all relevant information. This is not the case of the studies which rely on a wider range of data sources, but confine their sample to a process based on the initial search of a specific keyword, within the chosen database - a limitation present in the studies mentioned previously (e.g., Cornelius et al., 2006; Schildt et al., 2006; Reader and Watkins, 2006). In fact, obtaining data through such a broad process does not ensure that the interacting authors share similar research areas, as proposed by Zuccala (2006), which constitutes a handicap in those studies. Additionally, and compared to Teixeira (2011), who uses more journals than us, her data is restricted to a shorter period of time (2005-2010). 


\section{Searching for the 'invisible colleges' in the Entrepreneurship literature: methodological underpinnings}

\subsection{Bibliometrics as a tool for identifying the intellectual structure of a field}

Bibliometric methodology remains a fundamental tool to researchers by providing a concrete representation of the relationships among the products of science and enabling the mapping of documents generated by communication acts (Lievrouw, 1989). The term Bibliometrics gained notoriety with Pritchard, who suggested replacing the term "statistical bibliography" with the term "bibliometrics", describing it as the "the application of mathematical and statistical methods to books and other media of communication" (Pritchard, 1969: 349). Bibliometrics has been applied in monitoring the development of a specific scientific field, making use of journals and analyses of scientific areas (e.g., Ratnatunga and Romano, 1997; Phelan et al., 2002; Silva and Teixeira, 2008; Silva and Teixeira, 2009; Cruz and Teixeira, 2010) or individuals (e.g., Garfield, 1985); studying the intellectual development of a scientific field (e.g., Schildt et al., 2006; Cornelius et al., 2006; Culnan, 1987), and exploring the linkages between researchers (Reader and Watkins, 2006; McMillan and Casey, 2007). Beyond these applications, bibliometric methods are also crucial for research performance assessment (e.g., van Raan, 2003), serving as an instrument of science policy and research management (Glänzel, 2003), for decision-makers in government, management and institutional administration, such as universities (e.g., Garfield and Weeljams-Dorof, 1992; Moed, 2006), enabling them to evaluate research productivity for the purpose of resource allocation and promoting decisions (Laband and Piette, 1994).

Tables A1a-d (in Appendix) summarize and highlight several articles, according to their scientific area, and the main application areas of bibliometrics, namely: journal analysis (Table A1a), categorization of themes (Table A1b), intellectual structure (Table A1c) and invisible colleges (Table A1d). It is not meant to be a comprehensive list but rather a selection of the scientific areas based on its contiguity, in terms of knowledge, to our field of research - entrepreneurship - and on the similarity of employed methodology (as is the case of the scientific area of Industrial Relations \& Labour).

In terms of the application of bibliometric analysis to the field of economics, Laband and Piette (1994) updated the work of Liebowitz and Palmer (1984) and uncovered possible transformations in the economics journal market, between 1970 and 1990 . The authors justify that update with the usefulness of the Liebowitz-Palmer rankings to the evaluation of scholarly productivity by universities and colleges. To achieve their goal, Laband and Piette employed, among others tools that are detailed in Table A 1a, a widely-used bibliometric indicator, citation analysis (Smith, 1981; Kostoff, 2002). Citation-based indicators are viewed as forms of measurement of the impact or international visibility of scientific research (Narin, 1976; Garfield, 1979), based on the assumption that bibliometric instruments accurately reflect scientific activity (Rinia et al., 1998). In the field of entrepreneurship, Gamboa and Brouthers (2008) conducted a review of the articles published by nine selected journals (from the areas of entrepreneurship, international business and management) over two five-year time frames, 1986-1990 and 2000-2004, in order to discover the role of international entrepreneurship research in major entrepreneurship, international business, and management journals. Complementarily, Romano and Ratnatunga (1996) developed a citation analysis to assess the impact of small enterprise journals and articles during the period 1986-1992, with the intention of providing an objective evaluation of scholarly research and the relative importance of publications. 
Bibliometric analysis of topics and abstracts has recently been used in distinct research areas: structural change (Silva and Teixeira, 2008), evolutionary economics (Silva and Teixeira, 2009), regional studies (Cruz and Teixeira, 2010), and also entrepreneurship (Ratnatunga and Romano, 1997; Watkins and Reader, 2004; Van Praag and Versloot, 2008).

Ratnatunga and Romano (1997) provided a qualitative categorization of the topics, methodology and objectives of the most-cited articles, to identify the intellectual origins and directions of entrepreneurship research, whereas Watkins and Reader (2004) employed an original approach to identify current trends in the field of entrepreneurship. These authors used textual analysis and the ARPENT corpus as a data source, which allowed them to obtain a better understanding of the major topics in the literature. More recently, Van Praag and Versloot (2008) conducted a thoroughly research of title, abstract and full-text of 57 studies in order to discover if recent empirical evidence could corroborate the common notion that entrepreneurs are beneficial to the economy.

With regard to researching intellectual structures, authors in general employ co-citation analyses, exploring the relationships between the interdisciplinary specialties, namely management information systems (Culnan, 1987), innovation (Cottrill et al., 1989), and strategic management (Nerur et al., 2008). In entrepreneurship research, Cornelius et al. (2006) performed a bibliometric analysis of cited articles in three periods, 1986-1990, 1993-1997 and 2000-2004, in order to examine the intellectual structure of the field and assess its stage of maturation. The data is provide by the Social Sciences Citation Index, through a search of academic articles that include the word "entrep*" in the title, keywords, or abstract between 1986 and February 2005. The intention was to determine the field's research forefront, perceiving the most influential scholars and discovering the linkages among them and other authors. By evaluating the research output of key authors and the research topics over time, the authors found evidence to support the idea that entrepreneurship is evolving into a mature field. Similarly to the purpose of this latter work, Grégoire et al. (2006) studied the intellectual bases of entrepreneurship to understand the extent and nature of conceptual convergence in entrepreneurship research. In the study, they analyzed the co-citation networks provided by the articles published between 1981 and 2004 in the Frontiers of Entrepreneurship series and complemented it with an analysis by period (1981-1986, 1987-1992, 1993-1998 and 1999-2004). The emergence of consistent networks of co-citation provide evidence to support the argument that there has been convergence in entrepreneurship research over the last twenty-five years, although the overall levels of convergence observed were relatively low. In a complementary way, Schildt et al. (2006) conducted a bibliometric study and analyzed co-citations patterns of entrepreneurship-related articles, published during the period between 2000 and 2004, obtaining some evidence regarding the research directions of the subject, clarifying the state of entrepreneurship as a discipline and filling a gap in the literature. Twenty-five major research trends were identified; being present in the ten most-cited groups of study and subsequently explored their interrelatedness, through a co-citation network. The ten most-cited groups identified were: Entrepreneurial Networks and Resource Accumulation; Corporate Entrepreneurship and Venturing; Conceptualizations of Entrepreneurial Processes; Value Creation from Corporate Entrepreneurship; Alertness, Opportunity Creation, and Creative Destruction; Psychological Characteristics of Entrepreneurs, Qualitative Research Methods; Entrepreneurial Firm Survival and Growth; Societal Consequences of Entrepreneurship and Born-Global Firms (Schildt et al., 2006).

In the more restricted area of international entrepreneurship, Etemad and Lee (2003) studied the knowledge network of this sub-field from 1992 to 2000, through a 
Boolean progression of keywords that focused on the Social Sciences Citation Index database. By using a bibliometric methodology, namely citation analysis, they found that scholars of international entrepreneurship depend highly on the disciplines of international business and entrepreneurship to support their scientific research.

\subsection{Some descriptive information on the selected journals}

Leading academic journals have played an increasingly important role in the dissemination of scientific results (Ratnatunga and Romano, 1997; Stewart and Cotton, 2013). In this study, based on the three top Level I journals in the John Carroll University Classification of entrepreneurship journals (see Table A2), the Entrepreneurship Theory and Practice (ETP), Journal of Business Venturing (JBV) and Small Business Economics (SBE) were selected as core journals. This choice is also supported by that fact that several studies (e.g., Fried, 2003; Ritzberger, 2008; Stewart and Cotton, 2013) suggest that these three journals stand as the most highly ranked in the field of entrepreneurship.

ETP began publication as the American Journal of Small Business from 1976 until 1988, year when the journal changed to its current title. ETP is a scholarly journal, published bi-monthly at Baylor University, and covering a broad range of topics, in compliance with its ultimate goal of contributing to the development of the field of entrepreneurship. JBV started its publication in 1985 and is established as a scholarly forum that provides innovative insights into the phenomenon of entrepreneurship, publishing presently 6 issues a year. SBE is the youngest of the three journals, having begun in 1989. With four issues per year, SBE focuses on entrepreneurship and small business research.

Since their first publication to the end of 2008, the three journals published a total of 2716 articles (see Fig. 2) - Obituaries, corrections and editorial comments were not included. ETP, being the eldest, is the most prolific journal, with a total of 1015 articles. SBE, although the youngest journal, follows ETP with 979 articles against the 722 articles published in JBV. Analyzing the period from 1989 to 2008 - common to the three journals - SBE is the most prolific journal, surpassing ETP and JBV in number of articles every year, with the exception of 1993,2007 and 2008. JBV comes second, exceeding ETP, although ETP has been improving its publication numbers since 2005.

Table 1 provides a list of the 20 most prolific authors (i.e., with the highest number of published articles) for each journal until 2008, ordered by the total number of articles published in the three journals. The first three leading positions (black cells in Table 1) are different for each of the journals. James Chrisman (Mississippi State University, US) is the most prolific author on the list and is also ETP's most prolific author (although he occupies the 7th position in JBV and has not published any article in SBE). Ian MacMillan (University of Pennsylvania, US) and Roy Thurik (Erasmus University Rotterdam, NL) are, respectively, the leading contributors to JBV and SBE, although the first has not published any articles in ETP and SBE, and the second occupies a very low position in ETP and JBV. 


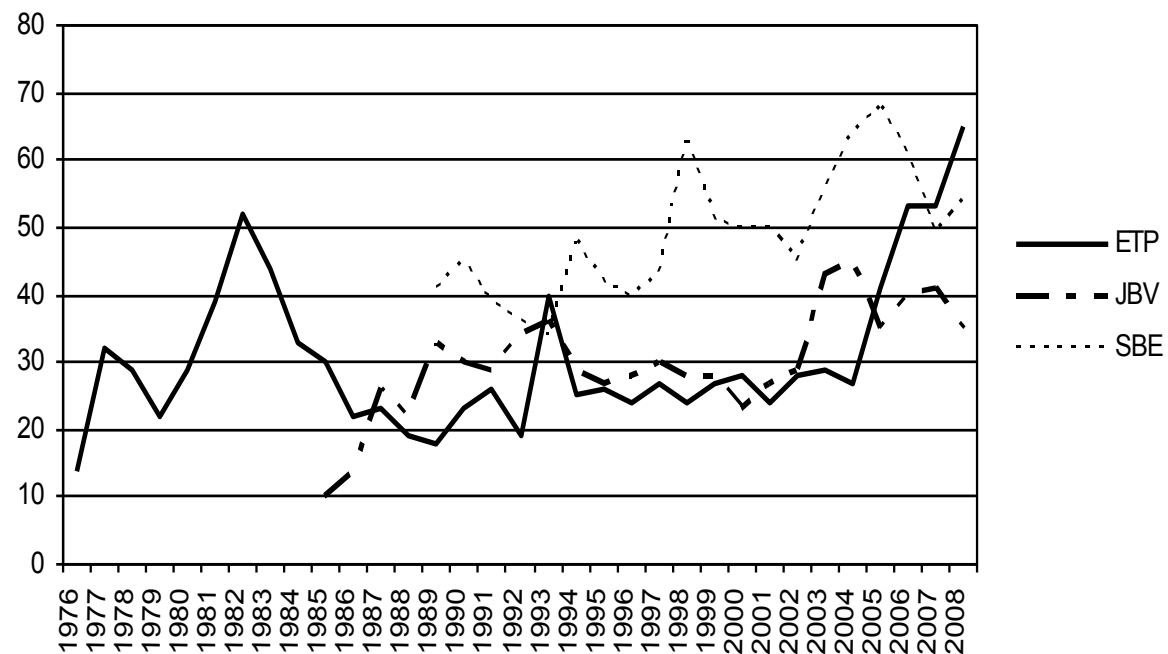

Fig. 2. Evolution of the number of articles per year published in ETP, JBV and SBE, 1976-2008

Source: Authors' computations based on our sample of articles collected manually for ETP and from Social Sciences Citation Index (SSCI) of the ISI Web of Science, for JBV and SBE, $(n=2716)$. The number of articles included in the years 1985 and 1986 for JBV, and 1989, 1990 and 1991 for SBE were collected manually, since they were unavailable in the ISI database.

With regard to the total number of articles published, as mentioned above, James Chrisman (Mississippi State University, US) is the author with the highest number of published articles. He is followed by William Gartner (Clemson University, US), Michael Wright (University of Nottingham, UK) and Shaker Zahra (University of Minnesota, US). These three authors belong to a set of sixteen authors common to all three journals (grey cells in Table 1). 
Table 1: List of the top 20 most prolific authors in ETP, JBV and SBE

\begin{tabular}{|c|c|c|c|c|c|c|c|c|}
\hline & & & Rank & & Numl & er of $A$ & rticles & \\
\hline Author & Affiliation & ETP & JBV & SBE & ETP & $\mathrm{JBV}$ & SBE & Total \\
\hline Chrisman, J.J. & $\begin{array}{l}\text { Mississippi State } \\
\text { University, US }\end{array}$ & 1 & 7 & - & 31 & 10 & 0 & 41 \\
\hline Gartner, W.B. & Clemson University, US & 4 & 3 & 40 & 15 & 16 & 3 & 34 \\
\hline Wright, M. & $\begin{array}{l}\text { University of } \\
\text { Nottingham, UK }\end{array}$ & 3 & 9 & 7 & 16 & 9 & 9 & 34 \\
\hline Zahra, S.A. & $\begin{array}{l}\text { University of Minnesota, } \\
\text { US }\end{array}$ & 2 & 5 & 177 & 17 & 13 & 1 & 31 \\
\hline Shepherd, D.A. & Indiana University, US & 8 & 2 & - & 11 & 17 & 0 & 28 \\
\hline $\begin{array}{l}\text { Macmillan, } \\
\text { I.C. }\end{array}$ & $\begin{array}{l}\text { University of } \\
\text { Pennsylvania, US }\end{array}$ & - & 1 & - & 0 & 25 & 0 & 25 \\
\hline Thurik, A.R. & $\begin{array}{l}\text { Erasmus University } \\
\text { Rotterdam, NL }\end{array}$ & 128 & 92 & 1 & 2 & 2 & 20 & 24 \\
\hline $\begin{array}{l}\text { Mcdougall, } \\
\text { P.P. }\end{array}$ & Indiana University, US & 9 & 10 & 69 & 11 & 9 & 2 & 22 \\
\hline Acs, Z.J. & $\begin{array}{l}\text { George Mason } \\
\text { University, US }\end{array}$ & - & - & 2 & 0 & 0 & 19 & 19 \\
\hline Sapienza, H.J. & $\begin{array}{l}\text { University of Minnesota, } \\
\text { US }\end{array}$ & 11 & 12 & 178 & 10 & 8 & 1 & 19 \\
\hline Westhead, P. & $\begin{array}{l}\text { University of Durham, } \\
\text { UK }\end{array}$ & 33 & 17 & 19 & 6 & 7 & 6 & 19 \\
\hline Birley, S. & $\begin{array}{l}\text { Bae Sistems (Retired), } \\
\text { UK }\end{array}$ & 26 & 6 & - & 7 & 11 & 0 & 18 \\
\hline Chua, J.H. & $\begin{array}{l}\text { University of Calgary, } \\
\text { CA }\end{array}$ & 6 & 30 & - & 13 & 5 & 0 & 18 \\
\hline $\begin{array}{l}\text { Audretsch, } \\
\text { D.B. }\end{array}$ & $\begin{array}{l}\text { Max Planck Institute of } \\
\text { Economics, DE }\end{array}$ & 78 & 61 & 4 & 3 & 3 & 11 & 17 \\
\hline Katz, J.A. & $\begin{array}{l}\text { Saint Louis University, } \\
\text { US }\end{array}$ & 10 & 42 & 70 & 11 & 4 & 2 & 17 \\
\hline Brush, C. & Babson College, US & 16 & 22 & 179 & 9 & 6 & 1 & 16 \\
\hline Kuratko, D.F. & Indiana University, US & 5 & 203 & - & 15 & 1 & 0 & 16 \\
\hline Covin, J.G. & Indiana University, US & 12 & 31 & - & 10 & 5 & 0 & 15 \\
\hline Reynolds, P.D. & $\begin{array}{l}\text { George Mason } \\
\text { University, US }\end{array}$ & 299 & 32 & 8 & 1 & 5 & 9 & 15 \\
\hline Shane, S. & $\begin{array}{l}\text { Case Western Reserve } \\
\text { University, US }\end{array}$ & 300 & 4 & - & 1 & 14 & 0 & 15 \\
\hline Busenitz, L. & $\begin{array}{l}\text { University of Oklahoma, } \\
\text { US }\end{array}$ & 20 & 23 & - & 8 & 6 & 0 & 14 \\
\hline Hisrich, R. & $\begin{array}{l}\text { Thunderbird School of } \\
\text { Global Management, US }\end{array}$ & 36 & 13 & 180 & 5 & 8 & 1 & 14 \\
\hline Hoy, F. & $\begin{array}{l}\text { University of Texas at El } \\
\text { Paso, US }\end{array}$ & 13 & 43 & - & 10 & 4 & 0 & 14 \\
\hline Cooper, A.C. & $\begin{array}{l}\text { Purdue University } \\
\text { (Retired), US }\end{array}$ & 79 & 8 & - & 3 & 10 & 0 & 13 \\
\hline Winn, J. & $\begin{array}{l}\text { University of Denver, } \\
\text { US }\end{array}$ & 7 & - & - & 13 & 0 & 0 & 13 \\
\hline Honig-Haftel, & Wichita State University, & 129 & 62 & 14 & 2 & 3 & 7 & 12 \\
\hline
\end{tabular}




\begin{tabular}{|c|c|c|c|c|c|c|c|c|}
\hline S. & US (Retired) & & & & & & & \\
\hline Storey, D.J. & $\begin{array}{l}\text { University of Warwick, } \\
\text { UK }\end{array}$ & - & - & 3 & 0 & 0 & 12 & 12 \\
\hline Wiklund, J. & Syracuse University, US & 17 & 93 & 181 & 9 & 2 & 1 & 12 \\
\hline Bruton, G. & $\begin{array}{l}\text { Texas Christian } \\
\text { University, US }\end{array}$ & 21 & 63 & - & 8 & 3 & 0 & 11 \\
\hline Cowling, M. & $\begin{array}{l}\text { Institute for Employment } \\
\text { Studies, UK }\end{array}$ & 301 & - & 5 & 1 & 0 & 10 & 11 \\
\hline Deeds, D. & $\begin{array}{l}\text { University of St. } \\
\text { Thomas, US }\end{array}$ & 80 & 14 & - & 3 & 8 & 0 & 11 \\
\hline Gatewood, E.J. & $\begin{array}{l}\text { Wake Forest University, } \\
\text { US }\end{array}$ & 22 & 94 & 182 & 8 & 2 & 1 & 11 \\
\hline Reid, G.C. & $\begin{array}{l}\text { University of St } \\
\text { Andrews, UK }\end{array}$ & 302 & - & 6 & 1 & 0 & 10 & 11 \\
\hline Sharma, P. & $\begin{array}{l}\text { Family Firm Institute, } \\
\text { Inc., US }\end{array}$ & 18 & 95 & - & 9 & 2 & 0 & 11 \\
\hline Steier, L. & $\begin{array}{l}\text { University of Alberta, } \\
\text { CA }\end{array}$ & 23 & 65 & - & 8 & 3 & 0 & 11 \\
\hline $\begin{array}{l}\text { De Cenzo, } \\
\text { D.A. }\end{array}$ & $\begin{array}{l}\text { Coastal Carolina } \\
\text { University, US }\end{array}$ & 14 & - & - & 10 & 0 & 0 & 10 \\
\hline Franklin, C.M. & $\begin{array}{l}\text { University of Southern } \\
\text { California, US }\end{array}$ & 15 & - & - & 10 & 0 & 0 & 10 \\
\hline Oviatt, B. & $\begin{array}{l}\text { University of New South } \\
\text { Wales, AU }\end{array}$ & 24 & 96 & - & 8 & 2 & 0 & 10 \\
\hline Phan, P.H. & $\begin{array}{l}\text { Johns Hopkins } \\
\text { University, US }\end{array}$ & - & 11 & 183 & 0 & 9 & 1 & 10 \\
\hline van Stel, A. & $\begin{array}{l}\text { EIM Business and Policy } \\
\text { Research, NL }\end{array}$ & 303 & 205 & 11 & 1 & 1 & 8 & 10 \\
\hline Baron, R.A. & $\begin{array}{l}\text { Oklahoma State } \\
\text { University, US }\end{array}$ & 130 & 18 & - & 2 & 7 & 0 & 9 \\
\hline Bird, B. & American University, US & 19 & - & - & 9 & 0 & 0 & 9 \\
\hline Carree, M. & $\begin{array}{l}\text { Maastricht University, } \\
\text { NL }\end{array}$ & - & 206 & 12 & 0 & 1 & 8 & 9 \\
\hline Cressy, R. & $\begin{array}{l}\text { University of } \\
\text { Birmingham, UK }\end{array}$ & - & - & 10 & - & - & 9 & 9 \\
\hline $\begin{array}{l}\text { Kellermanns, } \\
\text { F.W. }\end{array}$ & $\begin{array}{l}\text { Mississippi State } \\
\text { University, US }\end{array}$ & 25 & 207 & - & 8 & 1 & - & 9 \\
\hline Wagner, J. & $\begin{array}{l}\text { University of Lueneburg, } \\
\text { DE }\end{array}$ & - & - & 9 & - & - & 9 & 9 \\
\hline Abetti, P.A. & $\begin{array}{l}\text { Rensselaer Polytechnic } \\
\text { Institute, US }\end{array}$ & - & 15 & - & - & 8 & - & 8 \\
\hline Autio, E. & $\begin{array}{l}\text { Imperial College } \\
\text { London, UK }\end{array}$ & - & 208 & 15 & - & 1 & 7 & 8 \\
\hline Fitzroy, F.R. & $\begin{array}{l}\text { University of St } \\
\text { Andrews, UK }\end{array}$ & - & - & 13 & - & - & 8 & 8 \\
\hline Kaufmann, P.J. & Boston University, US & 305 & 19 & - & 1 & 7 & - & 8 \\
\hline $\begin{array}{l}\text { Venkataraman, } \\
\text { S. }\end{array}$ & $\begin{array}{l}\text { University of Virginia, } \\
\text { US }\end{array}$ & - & 16 & - & - & 8 & - & 8 \\
\hline Dant, R.P. & $\begin{array}{l}\text { University of Oklahoma, } \\
\text { US }\end{array}$ & - & 20 & - & - & 7 & - & 7 \\
\hline
\end{tabular}




\begin{tabular}{|c|c|c|c|c|c|c|c|c|}
\hline Henrekson, M. & $\begin{array}{l}\text { Research Institute of } \\
\text { Industrial Economics, SE }\end{array}$ & - & - & 16 & - & - & 7 & 7 \\
\hline Johnson, P. & Durham University, UK & 308 & - & 20 & 1 & - & 6 & 7 \\
\hline Karlsson, C. & $\begin{array}{l}\text { Jönköping University, } \\
\text { SE }\end{array}$ & - & - & 17 & - & - & 7 & 7 \\
\hline Levesque, M. & $\begin{array}{l}\text { University of Waterloo, } \\
\text { CA }\end{array}$ & - & 21 & - & - & 7 & - & 7 \\
\hline Watson, R. & $\begin{array}{l}\text { University of Durham, } \\
\text { UK }\end{array}$ & - & - & 18 & - & - & 7 & 7 \\
\hline
\end{tabular}

Source: Authors computations based on our sample of citations in ETP, JBV and SBE collected manually for ETP and from Social Sciences Citation Index (SSCI) of the ISI Web of Science, for JBV and SBE; the years 1985-1986 for JBV and 1989-1991 for SBE were not included, since they were not available on ISI database.

Note: Since the affiliation of the authors could be changed in the future, the validity of data concerning current affiliation is only guaranteed until August of 2009.

In spite of the existence of common authors in the three journals, SBE presents a very distinct ranking of entrepreneurship authors, with poor (or none) ranking positions for the majority of the authors listed in Table 1, with the exception of Michael Wright (University of Nottingham, UK). This results contrast with ETP and JBV, revealing clear signs of similarity: seven of the 20 most prolific authors in ETP and JBV are common to both journals and, at the same time, belong to the ten leading contributors to the total number of published articles. One could point out as a possible explanation for the differences found between ETP and JBV, on the one hand, and $\mathrm{SBE}$, on the other, is the stricter scope (economics) of the latter.

With respect to the affiliation of the most prolific authors, Indiana University (US) provides the highest number of contributing researchers (five), followed by the University of Durham (UK) and the University of Minnesota (US), with four contributors each. The Mississippi State University (US) and the University of Nottingham (UK) are each affiliated with three authors. Exploring the affiliation according to the core journal, Indiana University (US) and the University of Minnesota (US) are the largest providers of prolific authors to ETP and JBV, whereas, to SBE, the most relevant institution is the University of Durham (UK).

Extending the analysis to the country where the institutions affiliated with the leading contributors are located, the United States of America clearly stands out as the major provider of the most prolific authors, with a total of thirty-four leading authors, followed by the United Kingdom with twelve contributors. This result, however, differs according to the core journal. While the United States is responsible for about $84 \%$ and $81 \%$ of the most prolific authors to ETP and JBV, respectively, its contribution to SBE is around $15 \%$. In fact, the United Kingdom is the country that represents the largest proportion of prolific authors in SBE, a journal which receives contributions from a wider group of countries such as The Netherlands, Sweden and Germany.

We compiled and sorted the citations obtained from the source journals selected: ETP, JBV and SBE. JBV and SBE are indexed to the Social Sciences Citation Index (SSCI), managed by the Institute for Scientific Information (ISI)'s Web of Science Service, and export all the cited references included in SSCI of each of the articles published by JBV and SBE, from, respectively, 1987 and 1992 until February 2009. Cited references contained in articles from 1985 and 1986 for JBV and 1989, 1990 and 1991 for SBE were not included in the study due to their unavailability in ISI database. A different data gathering procedure was applied to the ETP journal, as SSCI did not provide any data prior to 2003. Thus, all the cited references of each article published between 1976 and February 2009 were collected manually and typed 
in order to be processed. The citation database of each journal consisted of the relevant details of every cited reference: name of the author(s) of the cited reference, title of the cited reference, published source (i.e., title of the journal or book) and year of publication. Citations extracted from SSCI, however, only refer to the first author of the cited reference (authors who do not obtain first authorship are not represented), which bias the results and constitutes a database limitation for JBV and SBE. As mentioned previously, we did not consider as "articles" obituaries, corrections and editorial comments. Therefore, references/citations included in editorials, research notes, corrections, comments, replies and rejoinders were excluded. The data files of each journal were transferred to Microsoft Office Excel 2003 which enabled the harmonization and validation of the references/citations. Due to differences of format and text codification (for instance, in the names of the authors, titles of the cited paper, titles of journals or books and year of edition), between journals and within the journal itself, Excel functions were used to standardize the sample of citations.

A total of 2.598 articles were published in ETP (40\%), JBV (27\%) and SBE (33\%), during the period considered (from 1976 (ETP), 1987 (JBV) and 1992 (SBE) to February 2009), which resulted in a total of 91.172 citations. Thus, the average number of citations provided per article was 35 . Analyzing separately for each of the journals, JBV has the highest average of citations - 44 - followed by SBE with 34 and, finally, ETP with an average of 30 citations. 


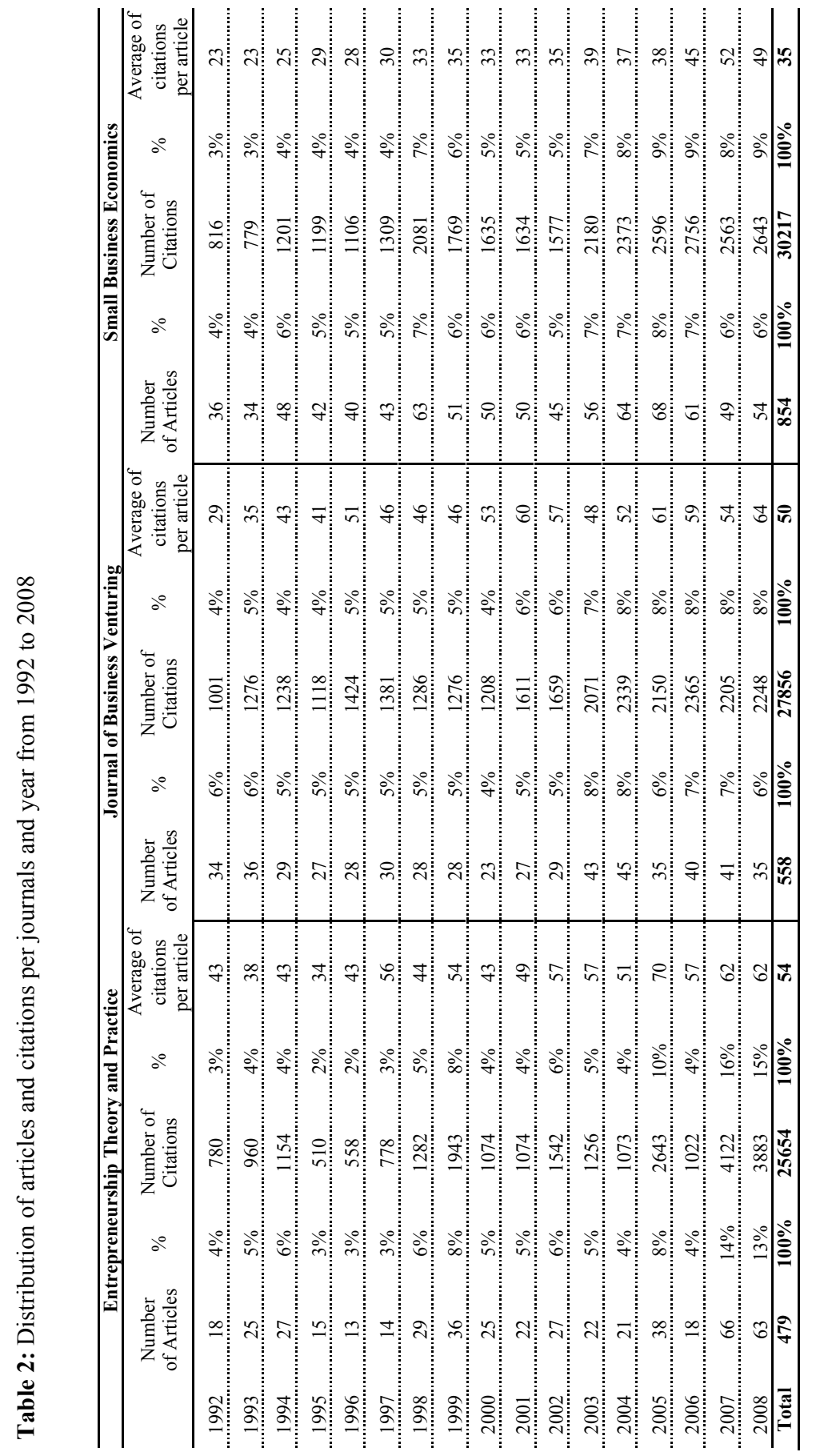


Since the period considered differs according to the selected journal, Table 2 provides some insights regarding data distribution during the common period to all three journals: 1992 to 2008 . ETP contributes with the lowest proportion of articles and citations, obtaining an average of 54 citations per article. Analyzing the evolution per year, ETP reveals an average increase since 2005. SBE, on the contrary, is the major publisher of articles that provided the largest proportion of citations, having the lowest average of citations per article.

After consolidating the citation databases, we were able to construct three distinct yet complementary rankings, for each of the core journals: the twenty most-cited (first in the case of SBE and JVB) authors; the ten most-cited studies and the twenty most-cited journals. The rankings allowed us to answer the first research question of the study, identifying the most-cited authors, studies (article or book), and journals, in each of the entrepreneurship journals selected. Once the key authors had been identified, we could then explore if there were similarities among the leading authors and answer the second research question, through an analysis that implied gathering personal data on the authors' educational background, research area and professional affiliation. The mapping of the intellectual groundings of the three core journals combined with the analysis of the relationships between the most-cited authors provided the fundamental tools to infer about the presence of invisible colleges in the scientific field of entrepreneurship, answering the last research question and achieving the main purpose of the study.

\section{$4 \quad$ Empirical results}

\subsection{The most-cited authors, studies and journals submission}

The most widely-cited author in ETP since its first publication to February 2009, is Michael Wright (University of Nottingham, UK). The author ranks 71st and 77th in JBV and SBE, respectively. The most cited first author in JBV, from 1987 to February 2009, is Arnold Cooper (Purdue University, US), who takes the 3rd and 37th positions in the ETP and SBE rankings, respectively. Zoltan Acs is the most-cited first author in SBE, during the period from 1992 to February 2009, raking 96th in ETP and 126th in SBE.

Table 3 presents the 20 most cited authors per journal, ordered by descending number of citations. The three rankings of the Top 20 most-cited authors only have one author in common: Howard Aldrich (University of North Carolina, US). Similarities regarding top cited authors are notoriously higher between ETP and JBV than with SBE. ETP and JBV have nine top cited authors common to them both, whereas JBV and SBE only share two authors, and ETP and SBE have no top author in common.

According to Zuccala (2006) (cf. Section 2), there are three main elements to take into consideration when defining an invisible college: influential scholars (i.e., most-cited authors); subject specialty (i.e., research areas) and information use environment (i.e., affiliation environment, such as institution and country). Following this framework, we assigned a main research area to each of the most-cited authors and analyzed, for each "core journal" and for all journals combined, the geographical distribution of the authors' current affiliation (Fig. 3).

Table 3: Ranking of the Top 20 most cited authors in ETP, JBV and SBE (name and number of citations) 


\begin{tabular}{|c|c|c|c|c|c|}
\hline \multicolumn{2}{|c|}{$\begin{array}{l}\text { Entrepreneurship Theory } \\
\text { and Practice (ETP) }\end{array}$} & \multicolumn{2}{|c|}{$\begin{array}{c}\text { Journal of Business } \\
\text { Venturing (JBV) }\end{array}$} & \multicolumn{2}{|c|}{$\begin{array}{l}\text { Small Business Economics } \\
\text { (SBE) }\end{array}$} \\
\hline Name & $\#$ & Name & $\#$ & Name & \# \\
\hline Wright, M. & 178 & Cooper, A. & 307 & Acs, Z. & 509 \\
\hline Zahra, S. & 168 & Aldrich, H. & 241 & Audretsch, D. & 508 \\
\hline Cooper, A. & 144 & MacMillan, I. & 213 & Storey, D. & 276 \\
\hline MacMillan, I. & 138 & Gartner, W. & 209 & Reynolds, P. & 258 \\
\hline Brush, C. & 122 & Miller, D. & 183 & Evans, D. & 248 \\
\hline Bygrave, W. & 121 & Porter, M. & 183 & Schumpeter, J. & 173 \\
\hline Chrisman, J. & 118 & Zahra, S. & 182 & Porter, M. & 130 \\
\hline Covin, J. & 118 & Shane, S. & 180 & Blanchflower, D. & 126 \\
\hline Aldrich, H. & 117 & Vesper, K. & 143 & Geroski, P. & 123 \\
\hline Hitt, M. & 115 & Hambrick, D. & 141 & Dunne, T. & 116 \\
\hline Miller, D. & 113 & Covin, J. & 135 & Jovanovic, B. & 116 \\
\hline Gartner, W. & 112 & Bygrave, W. & 130 & Cressy, R. & 112 \\
\hline Westhead, P. & 111 & Birley, S. & 129 & Bates, T. & 107 \\
\hline Sexton, D. & 107 & Eisenhardt, K. & 128 & Wagner, J. & 100 \\
\hline Reynolds, P. & 103 & Schumpeter, J. & 124 & Baumol, W. & 99 \\
\hline Sapienza, H. & 103 & Van de Ven, A. & 121 & Aldrich, $\mathrm{H}$. & 98 \\
\hline Hisrich, R. & 100 & Williamson, O. & 120 & Berger, A. & 97 \\
\hline Birley, S. & 90 & Brockhaus, R. & 118 & Caves, R. & 96 \\
\hline Dess, G. & 87 & Kanter, R. & 116 & Cohen, W. & 94 \\
\hline Hambrick, D. & 86 & Timmons, J. & 115 & Davis, S. & 93 \\
\hline & & & & Scherer, F. & 93 \\
\hline
\end{tabular}

Source: Own computations based on citations in ETP, JBV and SBE, collected manually for ETP and from Social Sciences Citation Index (SSCI) of the ISI Web of Science, for JBV and SBE. In the case of JBV and SBE citations refer only first authors.

Common to all three journals

Only common to JBV and SBE
Only common to ETP and JBV

Only common to ETP and SBE 


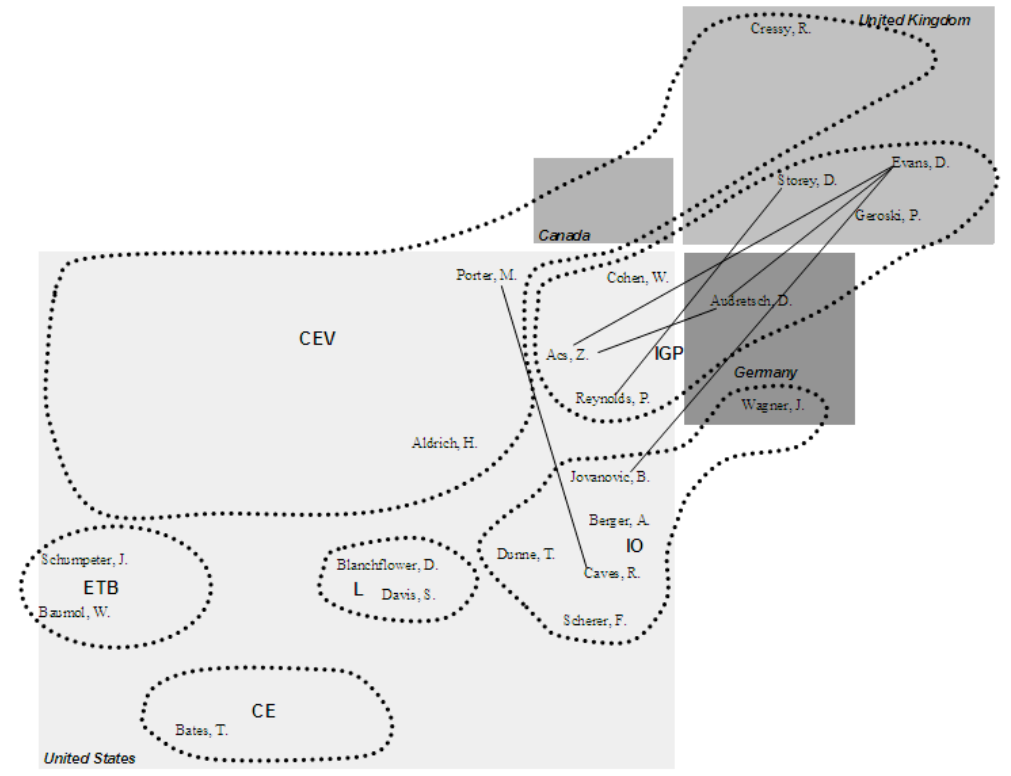

SBE

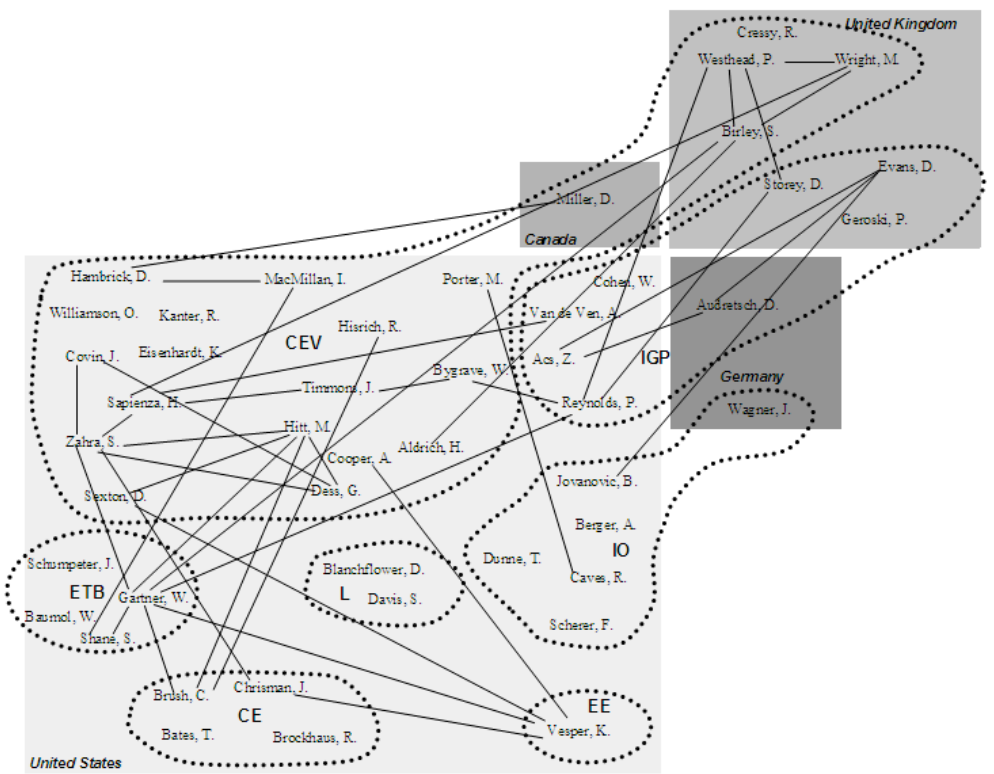

ALL

Legend: ETB - Entrepreneurship Theory Building; CE - Characteristics of the Entrepreneur; CEV Corporate and Entrepreneurship Venturing; EE - Entrepreneurship Education; IGP - Innovation, Growth and Policy; L - Labor; IO - Industrial Organization

Fig.1. Mapping the international scientific linkages of the most influential authors in entrepreneurship by 'core journal'

The designation of the core research areas is based on a comprehensive survey of the 
research topics in entrepreneurship (in Santos and Teixeira, 2009), which allowed for the establishment of five distinct research areas within the field of entrepreneurship. Santos and Teixeira (2009) identified eleven major topics on entrepreneurship literature: Entrepreneurship theory building; Entrepreneurial psychological issues; Demographic traits; Entrepreneurial context; Corporate entrepreneurship; Venture capital; Entrepreneurship education; Policy; Innovation; Growth and Regional. Due to the wide scope of academic interests reflected in the influential authors' publications, we aggregated these topics into five, so that we could assign only one major research area to each of the authors, which enabled mapping the constructions in this study. Furthermore, the analysis of the academic publications and areas of interest of the most-cited authors of each journal revealed that it was necessary to include two additional research areas (Labour and Industrial Organization), economics-oriented, outside the entrepreneurship field (Table 4).

Table 4: Areas of scientific research associated with top cited authors

\begin{tabular}{lc}
\hline \multicolumn{1}{c}{ Research Areas } & Abbreviaton \\
\hline Entrepreneurship Theory Building & ETB \\
Characteristics of the Entrepreneur & $\mathrm{CE}$ \\
Corporate and Entrepreneurship Venturing & $\mathrm{CEV}$ \\
Entrepreneurship Education & $\mathrm{EE}$ \\
Innovation, Growth and Policy & IGP \\
Labor & $\mathrm{L}$ \\
Industrial Organization & IO \\
\hline
\end{tabular}

Legend: ETB - Entrepreneurship Theory Building; CE - Characteristics of the Entrepreneur; CEV - Corporate and Entrepreneurship Venturing; EE - Entrepreneurship Education; IGP Innovation, Growth and Policy; L - Labour; IO - Industrial Organization.

Considering all the core journals, the United States is the most prominent country, covering around $79 \%$ of the most-cited authors. The United Kingdom comes in second, with $15 \%$. Germany and Canada are less prominent, affiliating, respectively, two and one of the influential authors in entrepreneurship research. With regard to research areas, CEV has the highest proportion of most-cited authors $(47 \%)$, followed by IGP $(17 \%)$ and IO $(13 \%)$. The other research areas have less influence. While this pattern is seen in the UK, in the US CEV remains the research area with the highest number of top cited scholars $(46 \%)$, followed by IO (14\%). IGP represents $11 \%$, along with CE and ETP. Overall, the US is the only country with influential scholars in all seven research areas.

By examining the map comprising all the core journals (Fig. 4), we can see that the most cited authors in entrepreneurship-specific areas collaborate with key authors from other research areas, particularly CVE, where different authors relate to other scholars from five distinct areas. The economics-oriented areas are the exception to this scenario, containing highly-cited authors who are rather isolated from each other, with occasional or no collaboration ties.

Comparing the mapping for the most-cited authors for each of the selected journals, we found that both ETP and JBV present similar intellectual structures, with respect to the research areas, EE being the exception - there are no key authors in this area in ETP. For both journals, CVE is the subject specialty involving the highest number of 
influential authors and the economics-oriented subject specialties of IO and L do not appeared in the set. The main difference between the two journals seems to lie on the areas of $\mathrm{CE}$ and $\mathrm{EE}$.

CE appears to be a more influential research area in ETP in comparison to JBV, namely through contributions from Candida Brush and James Chrisman (5th and 7th in ETP's top 20 most-cited authors, respectively), boosting collaboration between researchers from distinct subject specialities. In JBV, this area has only one influential author - Robert Brockhaus - with no visible collaborations. The opposite situation occurs with EE: although excluded in the ETP mapping, it plays a significant role in JBV, due to the work of Karl Vesper (9th in JBV's top 20 most-cited authors). Nevertheless, influential authors such as Gartner, Zahra, Covin, Hambrick, MacMillan, Aldrich and Birley and their collaborations remain common to both journals. The geographical distribution of the top cited authors is also very similar: both journals have no influential authors located in Germany, maintaining the US, Canada and the UK (although the UK concentrates a higher number of key scholars in ETP when compared to JBV). The results obtained support the assessment of existing similarities in the intellectual structure and linkages among influential authors for ETP and JBV, which suggests that they could be part of the same invisible college.

SBE's mapping is substantially different from the other two core journals. The core area with the highest number of most-cited authors is Innovation, Growth and Policy, IGP (with seven authors), followed by Industrial Organization, IO (with six authors). CEV, previously the top research area for ETP and JBV, occupies here the third position, with only three key authors. SBE is the only journal to contemplate the economics-oriented areas of IO and L and, contrarily to ETP and JBV, collaborations between influential authors from distinct subject specialties are almost nonexistent. Instead, the mapping of SBE unveils a high concentration of collaborations between the most-cited authors within the main research area - IGP. Additionally, SBE's top five authors belong to this subject specialty. The geographic distribution of the most-cited authors also differs: American dominion is counterbalanced by the UK and Germany. The two European countries account for more than half of the total key authors' affiliations in the core area of IGP, and three of these key scholars are among the top five authors in SBE. Canada is absent in SBE. The findings seem to indicate that the core journal SBE represents a rather distinct invisible college within the field of entrepreneurship.

The differences found above would not have surfaced if this study had been based on a single data source, thus emphasizing the importance of using three core journals to determine the existence of invisible colleges. Table 5 presents, for each of the selected journals, the top 10 most-cited studies, ranking them by number of citations.

Table 5. Ranking of the Top 10 most-cited studies in ETP, JBV and SBE

\begin{tabular}{|c|c|c|c|c|c|}
\hline & Author(s) & Date & Title & Source & $\begin{array}{l}\text { Number } \\
\text { citations }\end{array}$ \\
\hline \multirow{4}{*}{ ETP } & Schumpeter, J. & 1934 & $\begin{array}{l}\text { The theory of economic development: } \\
\text { An inquiry into profits, capital, credit, } \\
\text { interest, and the business cycle }\end{array}$ & - & 90 \\
\hline & Gartner, W. & 1988 & $\begin{array}{l}\text { "Who is an entrepreneur?" is the } \\
\text { wrong question }\end{array}$ & $\begin{array}{l}\text { American Journal } \\
\text { of Small Business }\end{array}$ & 63 \\
\hline & $\begin{array}{l}\text { Shane, S.; } \\
\text { Venkataraman, } \\
\text { S. }\end{array}$ & 2000 & $\begin{array}{l}\text { The promise of entrepreneurship as a } \\
\text { field of research }\end{array}$ & $\begin{array}{l}\text { Academy of } \\
\text { Management } \\
\text { Review }\end{array}$ & 59 \\
\hline & Barney, J. & 1991 & $\begin{array}{l}\text { Firm resources and sustained } \\
\text { competitive advantage }\end{array}$ & $\begin{array}{l}\text { Journal of } \\
\text { Management }\end{array}$ & 57 \\
\hline
\end{tabular}




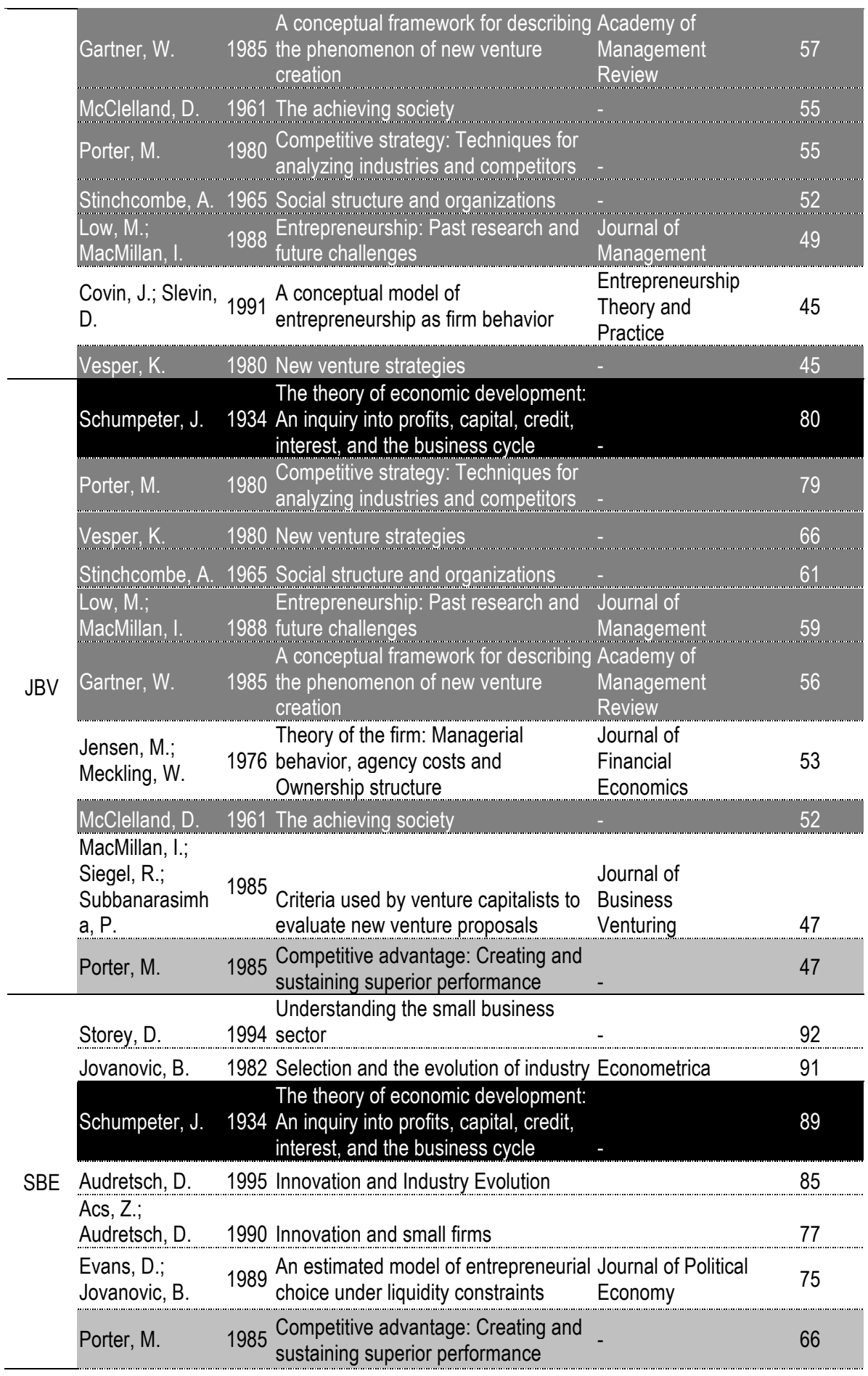


Schumpeter, J. 1942 Capitalism, socialism, and democracy -

Acs, Z:;

Audretsch, D.

1988 Innovation in large an Economic Review

Dunne, T.;

Roberts, M.; empirical analysis

Economic Review

49

Samuelson, $\mathrm{L}$.

Quarterly Journal

of Economics

Source: Authors computations based on our sample of citations in ETP, JBV and SBE, collected manually for ETP and from Social Sciences Citation Index of the ISI Web of Science, for JBV and SBE.

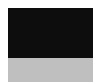

The most-cited study in ETP (90 citations) and JBV (80 citations) is the book, The theory of economic development: An inquiry into profits, capital, credit, interest, and the business cycle, a seminal contribution by Joseph Schumpeter to the conceptualization of entrepreneurial processes (Schildt et al., 2006). Schumpeter's book is also the only cited study common to all three journals and ranks as the 3rd most-cited study in SBE. The most-cited study in SBE (cited 92 times) is David Storey's book, Understanding the small business sector, where the author summarizes research on small businesses and draws conclusions from a policy perspective (Landström, 2005).

Again, we can identify several similarities between ETP and JBV regarding top-cited studies. ETP and JBV's rankings have seven frequently-cited studies in common, contrasting emphatically with SBE's ranking, which, besides Schumpeter's book, only has Michael Porter's book, Competitive advantage: Creating and sustaining superior performance, in common with JBV. The differences between ETP, JBV and SBE extend to the main subjects of the most-cited studies. Whereas in ETP and JBV's studies prevail on topics related with corporate entrepreneurship and venture capital, SBE's topics revolve around innovation combined with industrial issues. The evidence gathered and illustrated in Table 5 further corroborates the distinct intellectual structure underlying ETP and JBV, on the one hand, and SBE, on the other.

The most-cited journals in ETP, JBV and SBE are identified and ranked in Table 6. The most-cited journal in ETP is ETP itself. The same occurs with JBV and SBE. The results are not surprising and they were to some extent expected, since it has been established by several authors that a journal will cite itself more often than other citing journals (Ratnatunga and Romano, 1997). Considering the total number of citations from the three journals, JBV is the most influential journal, receiving the highest number of citations (a total of 5468 citations). ETP ranks as the second most-cited journal with 3329 citations, followed by Strategic Management Journal (3206 citations). SBE appears in 6th place, being cited by the core journals 1841 times. The evidence obtained is in line with previous studies that highlighted ETP and JBV as the journals with the greatest impact on the field of entrepreneurship (e.g., Dean et al., 2007; Chandler and Lyon, 2001; Shane, 1997; Romano and Ratnatunga, 1996). The relatively low 'impact' of SBE may, at least in part, be explained by its youth as it was only first published in 1989, whereas ETP started in 1976 and JBV in 1985.

The three journals have eight cited journals in common but their distribution and citation pattern differs from ETP and JBV to SBE. Whereas in ETP and JBV, six of 
the eight cited journals in common rank among the ten most-cited journals, SBE's top ten only includes three cited journals from the eight shared by all the core journals. The citation pattern also confirms the differences between SBE and the other two journals. In ETP and JBV, management-oriented journals dominate the top positions in the raking, whereas SBE gives preference to economics-oriented journals. The Academy of Management Review and the Journal of Finance are illustrative of the distinction between ETP/JBV and SBE. If the core journals' rankings were to only contemplate the ten most-cited studies, the gap between ETP/JBV and SBE would be even more visible: the selected journals would have only two of the most-cited journals in common, although ETP and JBV would still have nine journals in common. The similarities between ETP and JBV are notorious: from the twenty most-cited journals, sixteen are common to the two journals, and eight are exclusively common to the both.

The analysis of the most-cited authors, studies and journals attests to the multidisciplinary nature of research in entrepreneurship. The citations gathered arise from a wide range of disciplines across the social sciences, such as economics, management, marketing, finance, sociology and psychology. 


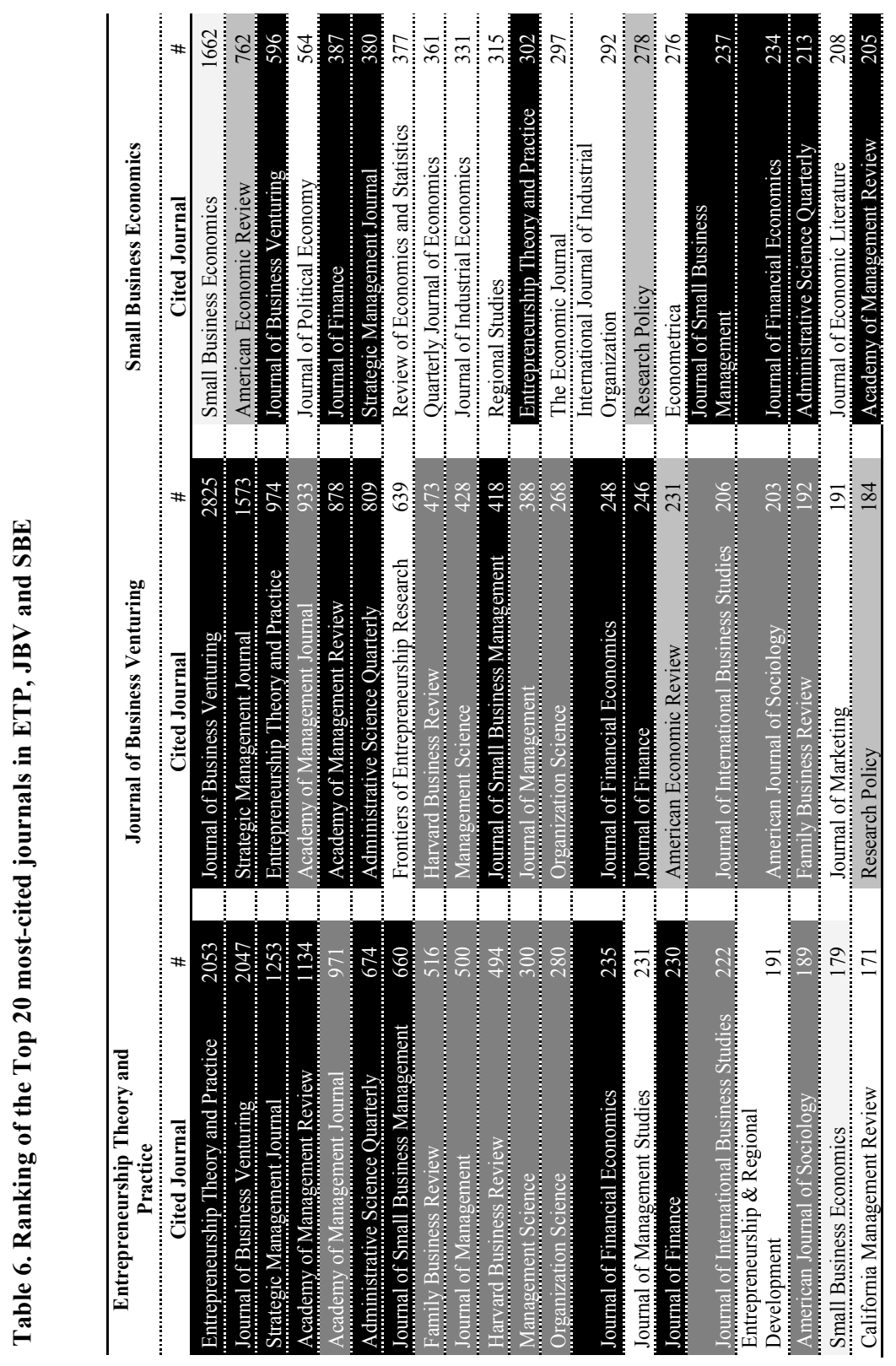

Source: Authors computations based on our sample of citations in ETP, JBV and SBE, collected manually for ETP and from Social Sciences Citation Index (SSCI) of the ISI Web of Science, for JBV and SBE.

Common to all three journals

Only common to JBV and SBE
Only common to ETP and JBV

Only common to ETP and SBE 
Several authors (e.g., Grégoire et al., 2006; Cornelius et al., 2006) report the diversity of entrepreneurship research, pointing out that this field attracts authors with different backgrounds and different methodological traditions. When comparing the most prolific authors with the most-cited authors, we observe that nineteen scholars fall into both categories, confirming that a highly productive author tends to stand as a highly influential author and, ultimately, vouches for the field's maturity. This conclusion is also congruent with Cornelius et al.'s (2006) results of an increasing internal orientation in entrepreneurship research. The fact that authors with research areas outside mainstream entrepreneurship research (such as IO and L) are among the most-cited authors appears to be a contradiction to the previous conclusion, since, as Cornelius et al. (2006) stress, entrepreneurship research has been increasingly self-reflective and the influence of outsiders (researchers who do not cite but are being cited by entrepreneurship researchers) has been decreasing over time. However, a closer look into the results reveals that the majority of outsiders comes from Small Business Economics, a more recent and economics-oriented journal than ETP and JBV, which underpins another finding of Cornelius et al. (2006): entrepreneurship scholars have increasingly specialized thematically, indicating that autonomous research groupings will develop.

The evidence obtained with regard to the most-cited authors, studies and journals, performed on the selected journals, characterizes the intellectual bases of the field of entrepreneurship and suggests that similarities between ETP and JBV could indicate the presence of an invisible college and, at the same, SBE's distinct intellectual structure may denote another invisible college.

\subsection{Research areas and educational and professional affiliation of top cited authors}

Through a (co)citation analysis, we identified 47 highly cited authors in the field of entrepreneurship. Co-citation techniques, although assessing the intellectual structure of a research field, do not capture all the insights related with the phenomenon of the invisible college (Zuccala, 2006). The issue here is, as Reader and Watkins (2006) put it, whether the most-cited authors are strictly part of a set of ideas constructed in the minds of the citers or there is an effective network of social interactions between the influential scholars. In order to more effectively answer this question, we complemented the (co)citation analysis, exploring the possible collaborations between highly cited authors, based on the analysis of their professional affiliation, educational background and main research area.

Table 7 presents personal data on the 47 most-cited authors (employer institution, research area and PhD granting school - the validity of authors' current professional affiliation is only guaranteed until August 2009; due to the absence of information, it was not possible to identify the granting school of one author and the graduation year of four authors), ranking them by the total number of citations obtained from the three selected journals. Among the top authors, David Audretsch is the scholar with the highest number of citations in all the core journals, although he is not part of ETP and JBV's top 20 rankings. With regard to the key authors' current affiliation represented in the column "employer institution" - we found that a total of 40 institutions employ the 47 most-cited authors (three authors, Miller, Hambrick and Sexton, are affiliated with two institutions each). Harvard University (US) employs the highest number of most-cited authors (5), followed by Babson College (US) and University of Minnesota (US), with three authors each and George Mason University (US) and New York University (US), both with two. The remaining 32 institutions employ only one influential author each. With respect to the organizations' geographical distribution, the US hosts the highest number of institutions (29), 
followed by the UK (7) and then, Germany and Canada, with two institutions each By combining the number of citations presented in Table 7, with the corresponding research area, for each cited author, we confirm the previous results regarding research areas. CVE is the main research area for twenty-two influential authors, IGP involves eight scholars, followed by IO, with six scholars. CE, ETB, L and EE are less prominent areas of interest.

CVE is the most frequent research area associated with ETP and JBV, whereas in SBE, IGP dominates, as mentioned previously. Beyond that, we can also draw further evidence: IGP, although not the most frequent research area, is the main research area for the two most-cited authors - Audretsch and Acs - among the 47. Another point should be stressed: the bottom most-cited authors are exclusively associated with SBE (they are seldom cited by ETP and JBV) and eight of them are related with economics-oriented areas, whereas authors with research areas not related with entrepreneurship do not rank in ETP's and JBV's top 20. These findings support the previous evidence suggesting that the three entrepreneurship core journals embody two (in)visible colleges in the entrepreneurship field: one associated with ETP and JBV and the other with SBE.

Educational background is also explored here by gathering information concerning the institution granting the $\mathrm{PhD}$ degree and year of graduation. We identify 31 distinct universities granting a doctoral degree to 44 of the most-cited authors. Harvard University (US) granted 4 PhDs, followed by the Stanford University US), University of Michigan (US) and University of Washington (US), with $3 \mathrm{PhDs}$ each. Pennsylvania State University (US), University of Chicago (US), University of Wisconsin (US) and University of London (UK) have two PhDs each among the most-cited authors. The remaining 23 universities granted a PhD to only one top cited author.

The geographical distribution of the cited authors' granting schools follows a similar pattern to that of their affiliation. The US concentrates a vast majority of the universities (33), followed by the UK (7). The only two differences are the inclusion of New Zealand and Austria, in the granting schools of the most-cited authors. In terms of graduation year, 44 of the most-cited authors took their PhDs a relatively long time ago (the most recent $\mathrm{PhD}$ degree was granted 17 years ago to Scott Shane). 
Table 7: Information on the professional affiliation, educational background and research area of the 47 most cited authors

\begin{tabular}{|c|c|c|c|c|c|c|c|c|}
\hline \multirow[b]{2}{*}{ Author } & \multicolumn{3}{|c|}{$\begin{array}{l}\text { Number of } \\
\text { Citations }\end{array}$} & \multirow[b]{2}{*}{$\begin{array}{l}\text { Employer } \\
\text { institution }\end{array}$} & \multirow[b]{2}{*}{$\begin{array}{l}\text { Secondary } \\
\text { unit }\end{array}$} & \multirow[b]{2}{*}{$\begin{array}{c}\text { Research } \\
\text { Area }\end{array}$} & \multirow{2}{*}{$\begin{array}{l}\text { Granting } \\
\text { School } \\
\text { (Ph.D.) }\end{array}$} & \multirow[b]{2}{*}{ Year } \\
\hline & 号 & 弯 & 岕 & & & & & \\
\hline 1 Audretsch, D. & 48 & 39 & 508 & $\begin{array}{l}\text { Max Planck } \\
\text { Institute of } \\
\text { Economics, DE }\end{array}$ & $\begin{array}{l}\text { Entrepreneurs } \\
\text { hip, Growth } \\
\text { and Public } \\
\text { Policy Group }\end{array}$ & IGP & $\begin{array}{l}\text { University of } \\
\text { Wisconsin-Ma } \\
\text { dison, US }\end{array}$ & 1980 \\
\hline 2 Acs, $Z$. & 32 & 37 & 509 & $\begin{array}{l}\text { George Mason } \\
\text { University, US }\end{array}$ & $\begin{array}{l}\text { School of } \\
\text { Public Policy }\end{array}$ & IGP & $\begin{array}{l}\text { Graduate } \\
\text { Faculty, The } \\
\text { New School, } \\
\text { US }\end{array}$ & 1980 \\
\hline 3 Cooper, A. & 144 & 307 & 73 & $\begin{array}{l}\text { Purdue } \\
\text { University } \\
\text { (Retired), US }\end{array}$ & $\begin{array}{l}\text { Krannert } \\
\text { School of } \\
\text { Management } \\
\text { (Retired) }\end{array}$ & CEV & $\begin{array}{l}\text { Harvard } \\
\text { University, US }\end{array}$ & 1962 \\
\hline 4 Aldrich, $\mathrm{H}$. & 117 & 241 & 98 & $\begin{array}{l}\text { University of } \\
\text { North Carolina, } \\
\text { US }\end{array}$ & $\begin{array}{l}\text { Kenan-Flagler } \\
\text { Business } \\
\text { School }\end{array}$ & CEV & $\begin{array}{l}\text { University of } \\
\text { Michigan, US }\end{array}$ & 1969 \\
\hline 5 Reynolds, P. & 103 & 94 & 258 & $\begin{array}{l}\text { George Mason } \\
\text { University, US }\end{array}$ & $\begin{array}{l}\text { School of } \\
\text { Public Policy }\end{array}$ & IGP & $\begin{array}{l}\text { Stanford } \\
\text { University, US }\end{array}$ & 1969 \\
\hline 6 Gartner, W. & 112 & 209 & 77 & $\begin{array}{l}\text { Clemson } \\
\text { University, US }\end{array}$ & $\begin{array}{l}\text { Arthur M. } \\
\text { Spiro Institute } \\
\text { for } \\
\text { Entrepreneuri } \\
\text { al Leadership }\end{array}$ & ETB & $\begin{array}{l}\text { University of } \\
\text { Washington, } \\
\text { US }\end{array}$ & 1982 \\
\hline 7 Zahra, S. & 168 & 182 & 38 & $\begin{array}{l}\text { University of } \\
\text { Minnesota, US }\end{array}$ & $\begin{array}{l}\text { Carlson } \\
\text { School of } \\
\text { Management }\end{array}$ & CEV & $\begin{array}{l}\text { University of } \\
\text { Mississippi, } \\
\text { US }\end{array}$ & 1982 \\
\hline 8 Porter, M. & 55 & 183 & 130 & $\begin{array}{l}\text { Harvard } \\
\text { University, US }\end{array}$ & $\begin{array}{l}\text { Harvard } \\
\text { Business } \\
\text { School }\end{array}$ & CEV & $\begin{array}{l}\text { Harvard } \\
\text { University, US }\end{array}$ & 1973 \\
\hline 9 MacMillan, I. & 138 & 213 & 14 & $\begin{array}{l}\text { University of } \\
\text { Pennsylvania, } \\
\text { US }\end{array}$ & $\begin{array}{l}\text { Wharton } \\
\text { School of } \\
\text { Business }\end{array}$ & CEV & $\begin{array}{l}\text { University of } \\
\text { South Africa, } \\
\text { ZA }\end{array}$ & 1975 \\
\hline 10 Storey, D. & 49 & 36 & 276 & $\begin{array}{l}\text { University of } \\
\text { Warwick, UK }\end{array}$ & $\begin{array}{l}\text { Warwick } \\
\text { Business } \\
\text { School }\end{array}$ & IGP & $\begin{array}{l}\text { Newcastle } \\
\text { University, UK }\end{array}$ & 1978 \\
\hline $\begin{array}{l}11 \text { Schumpeter, } \\
\mathrm{J.}{ }^{\dagger}\end{array}$ & 49 & 124 & 173 & $\begin{array}{l}\text { Harvard } \\
\text { University, US }\end{array}$ & - & EBT & $\begin{array}{l}\text { University of } \\
\text { Vienna, AT }\end{array}$ & 1906 \\
\hline 12 Miller, D. & 113 & 183 & 42 & $\begin{array}{l}\text { University of } \\
\text { Montréal and } \\
\text { University of } \\
\text { Alberta, CA }\end{array}$ & $\begin{array}{l}\text { Ecole des } \\
\text { Hautes } \\
\text { Etudes } \\
\text { Commerciales } \\
\text { and Family } \\
\text { Enterprise and } \\
\text { Strategy }\end{array}$ & CEV & $\begin{array}{l}\text { McGill } \\
\text { University, CA }\end{array}$ & 1976 \\
\hline 13 Shane, S. & 78 & 180 & 78 & Case Western & Weatherhead & EBT & University of & 1992 \\
\hline
\end{tabular}




\begin{tabular}{|c|c|c|c|c|c|c|c|c|}
\hline & & & & $\begin{array}{l}\text { Reserve } \\
\text { University, US }\end{array}$ & $\begin{array}{l}\text { School of } \\
\text { Management }\end{array}$ & & $\begin{array}{l}\text { Pennsylvania, } \\
\text { US }\end{array}$ & \\
\hline 14 Evans, D. & 13 & 48 & 248 & $\begin{array}{l}\text { Law and } \\
\text { Economics } \\
\text { Consulting } \\
\text { Group (LECG) } \\
\text { Europe, UK }\end{array}$ & - & IGP & $\begin{array}{l}\text { University of } \\
\text { Chicago, US }\end{array}$ & 1983 \\
\hline 15 Bygrave, W. & 121 & 130 & 33 & $\begin{array}{l}\text { Babson College, } \\
\text { US }\end{array}$ & - & CEV & & - \\
\hline 16 Birley, S. & 90 & 129 & 54 & $\begin{array}{l}\text { Bae Sistems } \\
\text { (Retired), UK }\end{array}$ & - & CEV & N/a & N/a \\
\hline 17 Covin, J. & 118 & 135 & 17 & $\begin{array}{l}\text { Indiana } \\
\text { University, US }\end{array}$ & $\begin{array}{l}\text { Kelley } \\
\text { School of } \\
\text { Business }\end{array}$ & CEV & $\begin{array}{l}\text { University of } \\
\text { Pittsburgh, US }\end{array}$ & 1985 \\
\hline 18 Wright, M. & 178 & 47 & 35 & $\begin{array}{l}\text { University of } \\
\text { Nottingham, UK }\end{array}$ & $\begin{array}{l}\text { Nottingham } \\
\text { University } \\
\text { Business } \\
\text { School }\end{array}$ & CEV & $\begin{array}{l}\text { University of } \\
\text { Nottingham, } \\
\text { UK }\end{array}$ & N/a \\
\hline 19 Brush, C. & 122 & 86 & 36 & $\begin{array}{l}\text { Babson College, } \\
\text { US }\end{array}$ & - & CE & & - \\
\hline 20 Westhead, P. & 111 & 47 & 85 & $\begin{array}{l}\text { University of } \\
\text { Durham, UK }\end{array}$ & $\begin{array}{l}\text { Durham } \\
\text { Business } \\
\text { School }\end{array}$ & CEV & $\begin{array}{l}\text { University } \\
\text { College of } \\
\text { Wales, UK }\end{array}$ & 1988 \\
\hline 21 Hambrick, D. & 86 & 141 & 12 & $\begin{array}{l}\text { Pennsylvania } \\
\text { State University } \\
\text { and Columbia } \\
\text { University, US }\end{array}$ & $\begin{array}{l}\text { Smeal College } \\
\text { of Business } \\
\text { and Graduate } \\
\text { School of } \\
\text { Business }\end{array}$ & CEV & $\begin{array}{l}\text { Pennsylvania } \\
\text { State } \\
\text { University, US }\end{array}$ & 1979 \\
\hline 22 Williamson, $\mathrm{O}$. & 35 & 120 & 79 & $\begin{array}{l}\text { University of } \\
\text { California, } \\
\text { Berkeley, US }\end{array}$ & $\begin{array}{l}\text { Walter A. } \\
\text { Haas School } \\
\text { of Business }\end{array}$ & CEV & $\begin{array}{l}\text { Carnegie } \\
\text { Mellon } \\
\text { University, US }\end{array}$ & 1963 \\
\hline 23 Vesper, K. & 64 & 143 & 15 & $\begin{array}{l}\text { University of } \\
\text { Washington, US }\end{array}$ & $\begin{array}{l}\text { University of } \\
\text { Washington } \\
\text { Business } \\
\text { School }\end{array}$ & EE & $\begin{array}{l}\text { Stanford } \\
\text { University, US }\end{array}$ & 1969 \\
\hline 24 Eisenhardt, K. & 63 & 128 & 26 & $\begin{array}{l}\text { Stanford } \\
\text { University, US }\end{array}$ & $\begin{array}{l}\text { Department of } \\
\text { Industrial } \\
\text { Engineering } \\
\text { and } \\
\text { Engineering } \\
\text { Management }\end{array}$ & CEV & $\begin{array}{l}\text { Stanford } \\
\text { University, US }\end{array}$ & 1982 \\
\hline 25 Hisrich, R. & 100 & 87 & 28 & $\begin{array}{l}\text { Thunderbird } \\
\text { School of Global } \\
\text { Management, } \\
\text { US }\end{array}$ & $\begin{array}{l}\text { Walker Center } \\
\text { for Global } \\
\text { Entrepreneurs } \\
\text { hip }\end{array}$ & CEV & $\begin{array}{l}\text { University of } \\
\text { Cincinnati, US }\end{array}$ & 1971 \\
\hline 26 Sexton, D. & 107 & 96 & 11 & $\begin{array}{l}\text { Ohio State } \\
\text { University } \\
\text { (Retired)/ Ewing } \\
\text { Marion } \\
\text { Kauffman } \\
\text { Foundation, US }\end{array}$ & - & CEV & $\begin{array}{l}\text { Ohio State } \\
\text { University, US }\end{array}$ & 1972 \\
\hline
\end{tabular}




\begin{tabular}{|c|c|c|c|c|c|c|c|c|}
\hline $\begin{array}{l}27 \text { Van de Ven, } \\
\text { A. }\end{array}$ & 81 & 121 & 11 & $\begin{array}{l}\text { University of } \\
\text { Minnesota, US }\end{array}$ & $\begin{array}{l}\text { Carlson } \\
\text { School of } \\
\text { Management }\end{array}$ & IGP & $\begin{array}{l}\text { University of } \\
\text { Wisconsin, US }\end{array}$ & 1972 \\
\hline 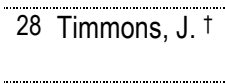 & 75 & 115 & 20 & $\begin{array}{l}\text { Babson College, } \\
\text { US }\end{array}$ & - & CEV & $\begin{array}{l}\text { Harvard } \\
\text { University, US }\end{array}$ & 1971 \\
\hline 29 Sapienza, H. & 103 & 80 & 27 & $\begin{array}{l}\text { University of } \\
\text { Minnesota, US }\end{array}$ & $\begin{array}{l}\text { Carlson } \\
\text { School of } \\
\text { Management }\end{array}$ & CEV & $\begin{array}{l}\text { University of } \\
\text { Maryland, US }\end{array}$ & 1989 \\
\hline 30 Bates, T. & 25 & 76 & 107 & $\begin{array}{l}\text { Wayne State } \\
\text { University, US }\end{array}$ & $\begin{array}{l}\text { Department of } \\
\text { Economics }\end{array}$ & CE & $\begin{array}{l}\text { University of } \\
\text { Wisconsin, US }\end{array}$ & 1972 \\
\hline 31 Brockhaus, R. & 63 & 118 & 13 & $\begin{array}{l}\text { Saint Louis } \\
\text { University, US }\end{array}$ & $\begin{array}{l}\text { John Cook } \\
\text { School of } \\
\text { Business }\end{array}$ & CE & $\begin{array}{l}\text { University of } \\
\text { Washington, } \\
\text { US }\end{array}$ & 1976 \\
\hline 32 Hitt, M. & 115 & 59 & 9 & $\begin{array}{l}\text { Texas A\&M } \\
\text { University, US }\end{array}$ & $\begin{array}{l}\text { Mays } \\
\text { Business } \\
\text { School }\end{array}$ & CEV & $\begin{array}{l}\text { University of } \\
\text { Colorado, US }\end{array}$ & 1974 \\
\hline 33 Chrisman, J. & 118 & 47 & 15 & $\begin{array}{l}\text { Mississippi State } \\
\text { University, US }\end{array}$ & $\begin{array}{l}\text { College of } \\
\text { Business and } \\
\text { Industry }\end{array}$ & CE & $\begin{array}{l}\text { University of } \\
\text { Georgia, US }\end{array}$ & 1986 \\
\hline 34 Dess, G. & 87 & 78 & 14 & $\begin{array}{l}\text { University of } \\
\text { Texas at Dallas, } \\
\text { US }\end{array}$ & $\begin{array}{l}\text { School of } \\
\text { Management }\end{array}$ & CEV & $\begin{array}{l}\text { University of } \\
\text { Washington, } \\
\text { US }\end{array}$ & 1980 \\
\hline 35 Baumol, W. & 20 & 48 & 99 & $\begin{array}{l}\text { New York } \\
\text { University, US }\end{array}$ & $\begin{array}{l}\text { Leonard N. } \\
\text { Stern School } \\
\text { of Business }\end{array}$ & ETB & $\begin{array}{l}\text { University of } \\
\text { London, UK }\end{array}$ & 1949 \\
\hline 36 Kanter, R. & 47 & 116 & 3 & $\begin{array}{l}\text { Harvard } \\
\text { University, US }\end{array}$ & $\begin{array}{l}\text { Harvard } \\
\text { Business } \\
\text { School }\end{array}$ & CEV & $\begin{array}{l}\text { University of } \\
\text { Michigan, US }\end{array}$ & 1967 \\
\hline 37 Cohen, W. & 11 & 53 & 94 & $\begin{array}{l}\text { Duke University, } \\
\text { US }\end{array}$ & $\begin{array}{l}\text { Fuqua School } \\
\text { of Business }\end{array}$ & IGP & $\begin{array}{l}\text { Yale } \\
\text { University, US }\end{array}$ & 1981 \\
\hline $\begin{array}{l}38 \text { Blanchflower, } \\
\text { D. }\end{array}$ & 5 & 9 & 126 & $\begin{array}{l}\text { Dartmouth } \\
\text { College, US }\end{array}$ & $\begin{array}{l}\text { Department of } \\
\text { Economics }\end{array}$ & L & $\begin{array}{l}\text { University of } \\
\text { London, UK }\end{array}$ & 1985 \\
\hline 39 Caves, $R$ & 10 & 34 & 96 & $\begin{array}{l}\text { Harvard } \\
\text { University, US }\end{array}$ & $\begin{array}{l}\text { Department of } \\
\text { Economics }\end{array}$ & 10 & $\begin{array}{l}\text { Harvard } \\
\text { University, US }\end{array}$ & 1958 \\
\hline 40 Geroski, P. ${ }^{\dagger}$ & 3 & 9 & 123 & $\begin{array}{l}\text { University of } \\
\text { London, UK }\end{array}$ & $\begin{array}{l}\text { London } \\
\text { Business } \\
\text { School }\end{array}$ & IGP & $\begin{array}{l}\text { University of } \\
\text { Warwick, UK }\end{array}$ & $N / a$ \\
\hline 41 Jovanovic, B. & 4 & 14 & 116 & $\begin{array}{l}\text { New York } \\
\text { University, US }\end{array}$ & $\begin{array}{l}\text { Department of } \\
\text { Economics }\end{array}$ & 10 & $\begin{array}{l}\text { University of } \\
\text { Chicago, US }\end{array}$ & 1978 \\
\hline 42 Cressy, R. & 4 & 12 & 112 & $\begin{array}{l}\text { University of } \\
\text { Birmingham, UK }\end{array}$ & $\begin{array}{l}\text { Birmingham } \\
\text { Business } \\
\text { School }\end{array}$ & CEV & $\begin{array}{l}\text { University of } \\
\text { Edinburgh, UK }\end{array}$ & $\mathrm{N} / \mathrm{a}$ \\
\hline 43 Scherer, F. & 11 & 24 & 93 & $\begin{array}{l}\text { Harvard } \\
\text { University, US }\end{array}$ & $\begin{array}{l}\text { John F. } \\
\text { Kennedy } \\
\text { School of } \\
\text { Government }\end{array}$ & 10 & $\begin{array}{l}\text { University of } \\
\text { Michigan, US }\end{array}$ & 1954 \\
\hline 44 Dunne, $T$. & 0 & 10 & 116 & $\begin{array}{l}\text { Federal Reserve } \\
\text { Bank of } \\
\text { Cleveland, US }\end{array}$ & $\begin{array}{l}\text { Research } \\
\text { Department }\end{array}$ & 10 & $\begin{array}{l}\text { Pennsylvania } \\
\text { State } \\
\text { University, US }\end{array}$ & 1987 \\
\hline 45 Berger, A. & 9 & 11 & 97 & $\begin{array}{l}\text { University of } \\
\text { South Carolina, } \\
\text { US }\end{array}$ & $\begin{array}{l}\text { Moore School } \\
\text { of Business }\end{array}$ & 10 & $\begin{array}{l}\text { University of } \\
\text { California, US }\end{array}$ & 1983 \\
\hline
\end{tabular}




\begin{tabular}{|c|c|c|c|c|c|c|c|c|}
\hline 46 Wagner, J. & 12 & 4 & 100 & $\begin{array}{l}\text { University of } \\
\text { Lueneburg, DE }\end{array}$ & $\begin{array}{l}\text { Institute of } \\
\text { Economics }\end{array}$ & 10 & $\begin{array}{l}\text { University of } \\
\text { Hannover, DE }\end{array}$ & 1984 \\
\hline 47 Davis, S. & 6 & 6 & 93 & $\begin{array}{l}\text { University of } \\
\text { Chicago, US }\end{array}$ & $\begin{array}{l}\text { Booth School } \\
\text { of Business }\end{array}$ & $L$ & $\begin{array}{l}\text { Brown } \\
\text { University, US }\end{array}$ & 1986 \\
\hline
\end{tabular}

Note: Authors are ordered by the total of citation in each journal. The grey cells indicate that the author is part of the Top 20 most cited authors in the designated journal.

Legend: ETB - Entrepreneurship Theory Building; CE - Characteristics of the Entrepreneur; CEV - Corporate and Entrepreneurship Venturing; EE - Entrepreneurship Education; IGP Innovation, Growth and Policy; L - Labor; IO - Industrial Organization.

According to Zuccala (2006), the Information Use Environment is a key element to identify invisible colleges, representing a scientific workspace where information-related behaviours occur. Based on this concept, we included additional information regarding the academic experience of the most-cited authors, so that our analysis captures all the (invisible) links between the key scholars. Thus, to infer if there are social correlations between the most frequently cited authors, in addition to $\mathrm{PhD}$ university and current professional affiliation, data on other current affiliations was gathered, besides the main employer institution, and present visiting academic institutions along with data on previous affiliations (the past affiliations prior to the cited authors' doctoral degree were disregarded) and past visiting academic institutions (Table A3 provides the information collected in detail with respect to these two items).

Fig. 4 illustrates the links between the most highly cited authors, based on the academic institutions that received the authors over their professional career. We only considered institutions that had received or are currently employing more than two top cited authors, which gave us a total of 24 institutions. The map represents the links between a total of 44 authors, across 24 organizations. Each of the top cited authors is identified by their ranking as established in Table 7, as well as the colour of the respective research area. Each link is represented by straight lines and denotes that at least one top cited author worked in the two linked institutions. An overall analysis of the map tells us that all institutions have received at least one top cited author, which suggests a substantial degree of linkage among the most-cited authors in entrepreneurship research.

The connections between the institutions and number of influential authors associated with them are distinct, according to each institution. Harvard University (US) is the institution that gathers the highest number of top cited authors (9), followed by the University of Pennsylvania (US), with 7 key authors. A total of 12 institutions is linked to 3 top cited authors. The University of Pennsylvania (US) holds the highest number of links (11), which implies that top cited authors connect with others, through 11 distinct institutions. The University of London (UK) comes in second, with connections to 10 institutions. The least interactive institutions, among the top ones, are the University of Michigan (US) and the University of Washington (US), with 2 and 3 links, respectively.

It should be noted that the number of top cited authors associated with an institution is not, per se, an indication of the degree of connectivity between influential authors. For instance, the University of Washington (US) hosts 4 top cited authors but only links with 3 other institutions. 


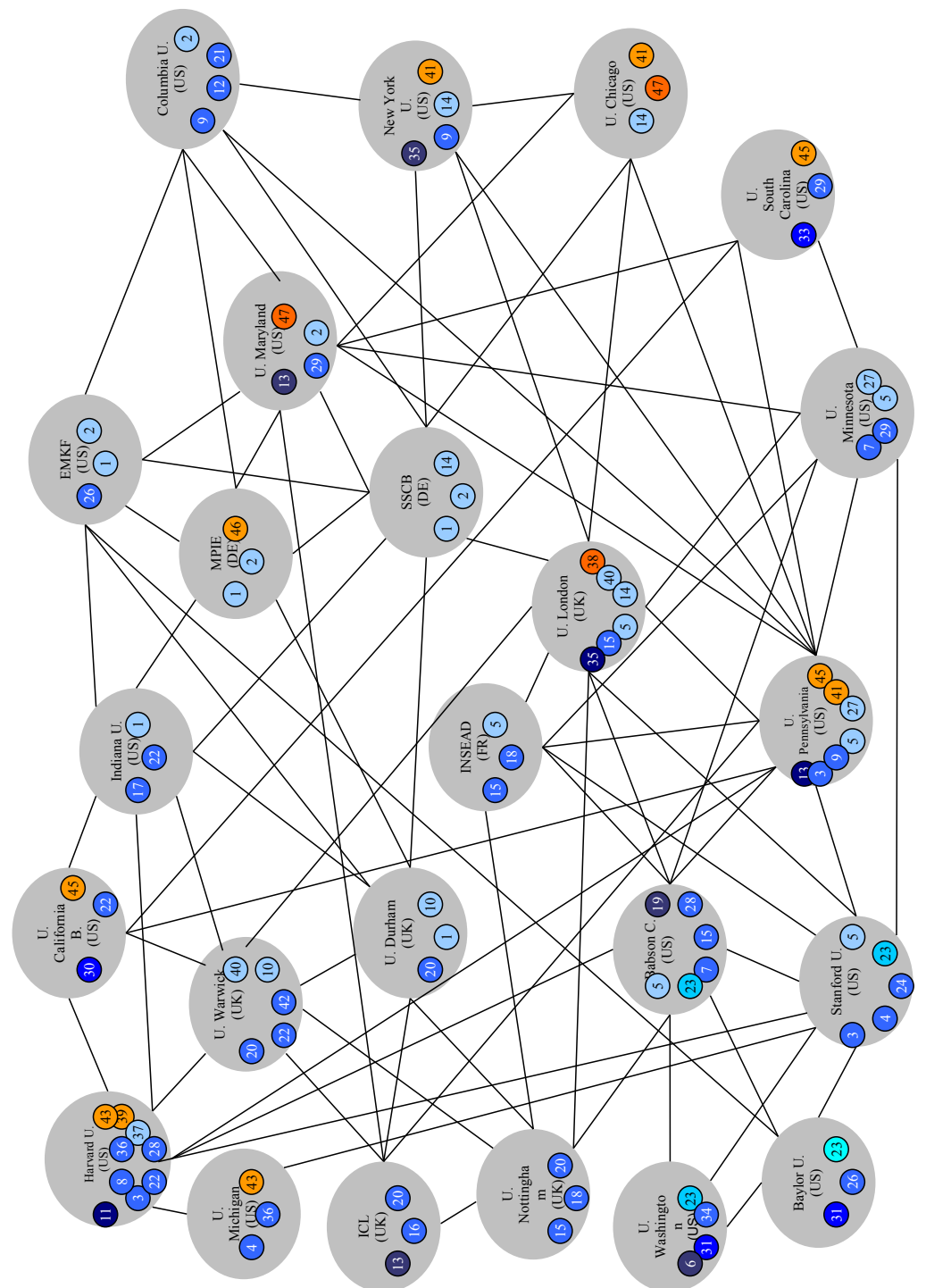

Fig. 2. Mapping links among top cited authors in entrepreneurship scientific area

Note: Each link means that at least one top cited author worked in the two linked organizations

\begin{tabular}{|c|l}
\hline ETB & Entrepreneurship Theory Building \\
EE & Entrepreneurship Education \\
CEV & $\begin{array}{l}\text { Corporate and Entrepreneurship } \\
\text { Venturing }\end{array}$ \\
\hline IO & Industrial Organization
\end{tabular}

CE

IGP

Characteristics of the Entrepreneur

Innovation, Growth and Policy

IO Industrial Organization 
On the other hand, the Social Science Centre of Berlin (DE) receives only 3 top cited authors, but establishes connections with 9 distinct institutions, which attests to the top cited authors' professional mobility, confirmed when we identify two of the cited authors, Audretsch and Acs, the two most-cited authors in our study and renowned academics, with a vast and prolific career.

An analysis on the research area of the 44 most-cited authors indicates that the degree of collaboration, represented by the links between institutions, agrees with the initial distribution of authors by research areas, i.e., the majority of the links established belong to top cited authors, whose main research area is CVE, with IGP appearing in second, followed by IO. The exception to this pattern comes from the EE research area that, with only one top cited author, connects with 4 other institutions, surpassing the research area of Labour (L) with two influential authors but no established collaborations outside their current affiliation. The evidence obtained indicates that top cited authors are highly connected, which is particularly visible in the research areas of CVE and IGP.

\section{Conclusions}

The disciplinary rules and research problems of a scientific domain and their acknowledgment by scholars within that domain are rooted in the internal ties that link scientists with similar research interests in the form of what Crane (1972) calls "invisibles colleges". In this sense, Invisible Colleges are valuable instruments to identify processes of knowledge dissemination and monitor the dynamics of scientific developments (Reader and Watkins, 2006).

Identifying the most-cited authors, studies and journals for the three core journals selected allowed us to explore the intellectual structure of entrepreneurship research. Evidence supports the multidisciplinary nature of the field of entrepreneurship, since results show that highly influential authors in the field are working in several subject specialties, including research areas that are not so directly focused on entrepreneurship, such as economics.

These "non-entrepreneurship" researchers are highly related with the specific orientation of each of the core journals. The present study empirically corroborates the idea that ETP and JBV are the most influential journals in the field of entrepreneurship and SBE is more specialized and economics-oriented. In fact, the (co)citation analysis confirms several similarities between ETP and JBV regarding the most cited authors, studies and journals and main research area, as well as the distinct intellectual structure of SBE.

Additionally, by collecting personal data regarding the top cited authors' current and past professional affiliation, educational background and combining it with the research areas assigned, it was possible to infer about the social ties established among the most influential authors. The results reveal that 44 key authors are highly linked among themselves, through 24 different institutions where they developed or are currently developing their work.

The two-stage procedure enabled finding the key elements to assess the existence of invisible colleges: social actors (the most-cited authors); subject specialty (research areas) and information use environment (professional affiliation of the most-cited authors). Formal and informal communication is represented by, respectively, the most-cited studies/journals and professional affiliation linkages. Accordingly, we identified two invisible colleges: one associated with ETP and JBV and the other associated with SBE. The results obtained are summarized in Fig. 5. Social actors are represented by the top five most-cited authors of each core journal; the scientific 
research area that attracts the highest number of most-cited authors is the "subject specialty", and the information use environment is defined by the professional affiliation where the most frequently cited authors currently work (until August 2009). Formal and informal communication is given, respectively, by the top five studies and journals for each of the three journals and the linkages extracted from information regarding top cited authors' current and past affiliations and $\mathrm{PhD}$ granting affiliation.

Based on an analysis on the core journals (ETP, JBV and SBE), we conclude that there are two invisible colleges in the field of entrepreneurship. The first invisible college is focused specifically on entrepreneurship research, the key orientation of ETP and JBV. The similarities between these two journals were a constant in all the stages of the study. The second invisible college is originated by the evolution of the entrepreneurship field into an increasingly specialized thematic discipline, developing autonomous research groupings, such as the one represented by SBE.

This study suffers from a series of limitations that must be highlighted. First, only one research area was imputed to each top cited author, which narrows down the academic scope of the researchers. The inclusion of more than one area of research would have been insightful to a better understanding of the social network formed by key scholars. Second, the analysis although involving a rather long time span is quite static; to compare the overall analysis with by-period analyses would provide insights regarding the evolution of the field which would enrich the research. Third, the subjective nature of the key element, "informal communication relations", underlying the concept of invisible colleges, raises some concern. We employed data regarding professional affiliations and educational background, but other methods, such as direct questionnaires, mailings, conference participation, could have been used.

Future research on the matter could combine bibliometric techniques with ethnographic methods of research so as to enhance our interpretation of the invisible college phenomenon. Nevertheless, we still believe that identifying and analyzing the two invisible colleges in entrepreneurship research provides a useful understanding of the scientific discipline, enlightening researchers, students and the public in general. 


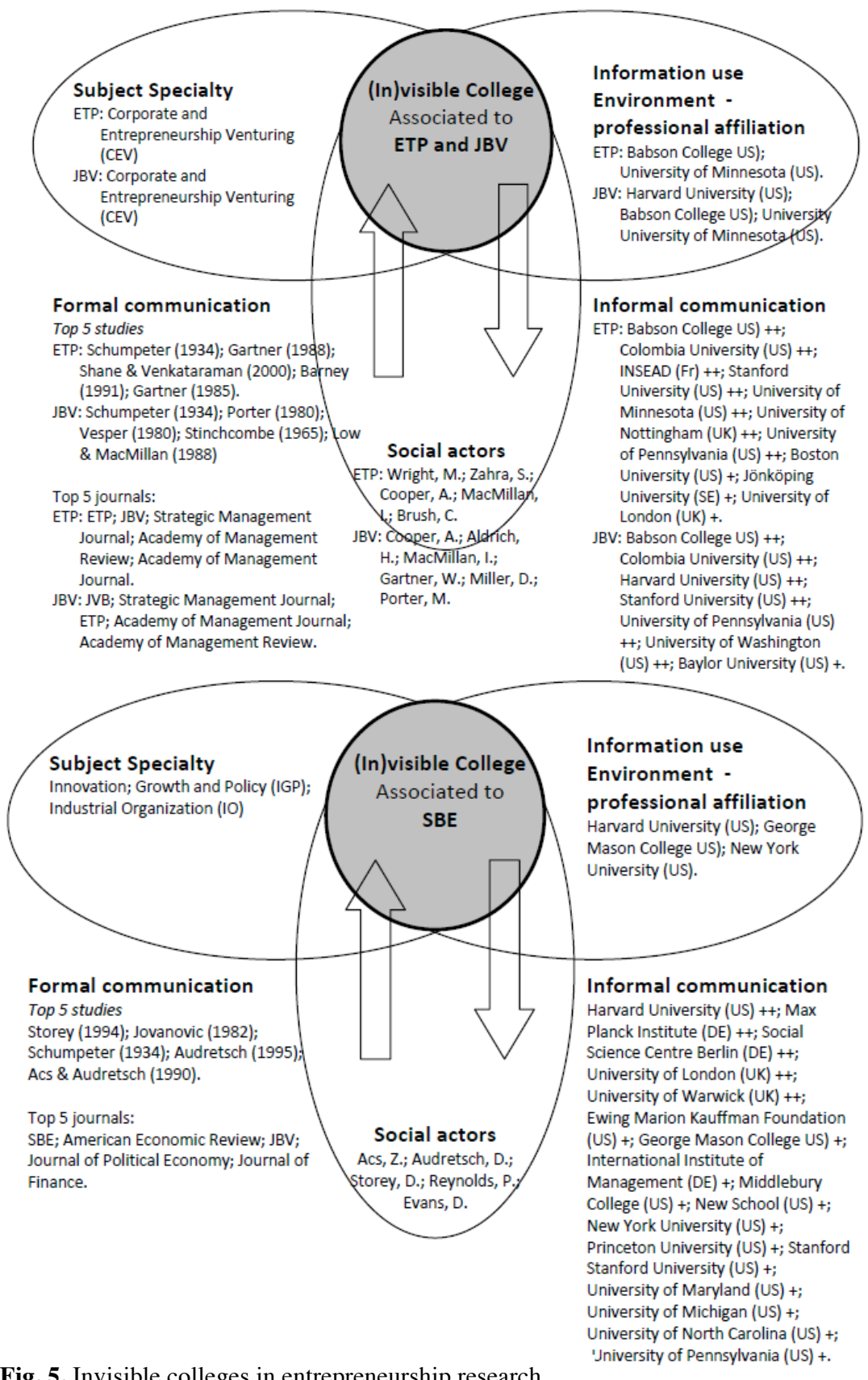

Fig. 5. Invisible colleges in entrepreneurship research

Notes: Universities listed in "Informal Communication" have affiliated at least 3 of the most-cited authors in the Journal $(++)$ or have affiliated 2 of the most-cited authors in the Journal who have more than 3 links with universities that also affiliates most-cited authors in the Journal(+) 


\section{References}

Aldrich, H.E. (2012). The emergence of entrepreneurship as an academic field: A personal essay on institutional entrepreneurship. Research Policy 41, 12401248.

Bayer, A.E., Smart, J.C., \& McLaughlin, G.W. (1990). Mapping intellectual structure of a scientific subfield through author cocitations. Journal of the American Society for Information Science, 41(6), 444-452.

Bellardo, T. (1980). The use of co-citations to study science. Library Research, 2(3), 231-237.

Carey, J. (2011). Faculty of 1000 and VIVO: invisible colleges and team science. Issues in Science and Technology Librarianship DOI: 10.5062/F4F769GT, in http://www.istl.org/11-spring/article1.html, accessed in December 2013.

Carlsson, B., Braunerhjelm, P., McKelvey, M., Olofsson, C., Persson, L., \& Ylinenpää, H. (2013). The evolving domain of entrepreneurship research. Small Business Economics 41, 913-930.

Casey, D., \& McMillan, G. (2008). Identifying the "Invisible Colleges" of the British Journal of Industrial Relations: A Bibliometric and Social. Industrial and Labor Relationship Review, 62(1), 126-132.

Chandler, G.N., \& Lyon, D.W. (2001). Issues of research design and construct measurement in entrepreneurship research: The past decade. Entrepreneurship Theory and Practice, 25(4), 101-113.

Cornelius, B., Landström, H., \& Persson, O. (2006). Entrepreneurial studies: The dynamic research front of a developing social science. Entrepreneurship Theory and Practice, 30(3), 375-397.

Cottrill, C.A., Rogers, E.M., \& Mills, T. (1989). Co-citation analysis of the scientific literature of innovation research traditions: Diffusion of innovations and technology transfer. Knowledge, 11(2), 181-208.

Crane, D. (1972), Invisible colleges: diffusion of knowledge in scientific communities, Chicago: University of Chicago Press.

Cruz, S., \& Teixeira, A.A.C. (2010). The evolution of the cluster literature: shedding light on the regional science-regional studies debate. Regional Studies. 44(9), 1263-1288.

Culnan M.J. (1987). Mapping the Intellectual Structure of MIS, 1980-1985: A Co-Citation Analysis. MIS Quarterly, (11)3: 340-353.

Dean, M.; Shook, C., \& Payne, G. (2007), "The past, present and future of entrepreneurship research: data analytic trends and training. Entrepreneurship Theory and Practice, 31(4), 601-618.

Dos Santos, B.L., Holsapple, C.W., \& Ye, Q. (2011). The intellectual influence of entrepreneurship journals: a network analysis. Entrepreneurship Theory and Practice. 35(4), 735-754.

Etemad, H., \& Lee, Y. (2003). The knowledge network of international entrepreneurship: theory and evidence. Small Business Economics, 20(1), 5-23.

Finkle, T.A. (2007). Trends in the market for entrepreneurship faculty from 1989-2005. Journal of Entrepreneurship Education, 10: 1-25.

Fried, V.H. (2003). Defining a forum for entrepreneurship scholars. Journal of 
Business Venturing, 18(1), 1-11 .

Gamboa, E.C., \& Brouthers, L.E. (2008). How international is entrepreneurship?. Entrepreneurship Theory and Practice, 32(3), 551-558.

Garfield, E. (1979). Is Citation a legitimate evaluation tool?. Scientometrics, 1(4), 359-375.

Garfield, E. (1985). In tribute to Derek John de Solla Price: a citation analysis of little science, big science. Scientometrics, 7(3-6), 487-503.

Garfield, E., Malin, M.V., \& Small, H. (1978). Citation data as science indicators" in Elkana, Y., Lederberg, J., Merton, R.K., Thackray, A., Zuckerman, H. (Eds), Toward a metric of science: the advent of science indicators, New York: John Wiley, 179-207.

Garfield, E., \& Weeljams-Dorof, A. (1992). Citation data: their use as quantitative indicators for science and technology evaluation and policy-making. Science \& Public Policy, 19(5), 321-327.

Gartner, W.B. (2013). Creating a community of difference in entrepreneurship scholarship. Entrepreneurship \& Regional Development: An International Journal. 25(1-2), 5-15.

Gmür, M. (2003). Co-citation analysis and the search for invisible colleges: a methodological evaluation. Scientometrics, 57(1),1-31.

Grégoire, D., Noël, M.X., Déry, R., \& Béchard, J.-P. (2006). Is there conceptual convergence in entrepreneurship research? A co-citation analysis of Frontiers of Entrepreneurship Research, 1981-2004. Entrepreneurship Theory and Practice, 30(3), 333-373.

Kostoff, R.N. (2002). Citation analysis of research performer quality. Scientometrics, 53(1), 49-71.

Laband, D.N., \& Piette, M.J. (1994). The relative impacts of economics journals: 1970-1990. Journal of Economic Literature XXXII, 32(2), 640-666.

Landström, H. (2005), Pioneers in Entrepreneurship and Small Business Research, New York: Springer.

Landström, H., Harirchi, G., \& Åström, F. (2012). Entrepreneurship: Exploring the knowledge base. Research Policy 41, 1154- 1181.

Liebowitz S.J., \& Palmer, J.P. (1984). Assessing the relative impacts of economics journals. Journal of Economic Literature, 22(1), 77-88.

Lievrouw, L. (1989). The invisible college reconsidered: bibliometrics and the development of scientific communication theory. Communication Research, 16(5), 615-628.

McMillan, G. (2008) "Mapping the invisible colleges of R\&D Management. $R \& D$ Management, 38(1), 69-83.

McMillan, G., \& Casey, D. (2007). Research note: identifying the invisible colleges of British Journal of Industrial Relations: A Bibliometric and Social Network Approach. British Journal of International Relations, 45(4), 815-828.

Moed, H.F. (2006), Bibliometric rankings of world universities, CWTS Report 2006-01, Available at http://www.cwts.nl/hm/bibl_rnk_wrld_univ_full.pdf.

Narin, F. (1976), Evaluative bibliometrics: The use of publication and citation analysis in the evaluation of scientific activity. Cherry Hill, N.J.: Computer Horizons.

Nerur, S., Rasheed, A.A., \& Natarajan, V. (2008). The intellectual structure of strategic management field: an author co-citation analysis. Strategic 
Management Journal, 29(3), 319-36.

Phelan, S.E., Ferreira, M., \& Salvador, R. (2002). The first twenty years of the Strategic Management Journal. Strategic Management Journal, 23(12), 1161-1168.

Price, D. J. de Solla. (1971). Some remarks on elitism in information and the invisible college phenomenon in science. Journal of the American Society for Information Science, 22, 74-75.

Pritchard, A. (1969). Statistical bibliography or bibliometrics?. Journal of Documentation 25(4), 348-349.

Ratnatunga, J., \& Romano, C. (1997). "A citation classics" analysis of articles in contemporary small enterprise research. Journal of Business Venturing, 12(3), $197-212$.

Reader, D., \& Watkins, D. (2006). The social and collaborative nature of entrepreneurship scholarship: A co-citation and perceptual analysis. Entrepreneurship Theory and Practice, 30(3), 417-441.

Rinia, E.J., van Leeuwen, Th.N., van Vuren, H.G., \& van Raan, A.F.J. (1998). Comparative analysis of a set of bibliometric indicators and central peer review criteria - Evaluation of condensed matter physics in the Netherlands. Research Policy, 27(1), 95-107.

Romano, C., \& Ratnatunga, J. (1996). A citation analysis of the impact of journals on contemporary small enterprise research. Entrepreneurship Theory and Practice, 20(3), 7-22.

Santos, C., \& Teixeira (2009). The evolution of the literature on entrepreneurship. Uncovering some under researched themes. FEP Working Paper, Universidade do Porto.

Sarasvathy, S.D., \& Venkataraman, S. (2011). Entrepreneurship as method: open questions for an entrepreneurial future. Entrepreneurship Theory and Practice. 35(1), 113-135.

Schildt, H.A., Zahra, S.A., \& Sillanpää, A. (2006). Scholarly communities in entrepreneurship research: A co-citation analysis. Entrepreneurship Theory and Practice, 30(3), 399-415.

Shane, S. (1997). Who is publishing the entrepreneurship research?" Journal of Management, 23(1), 83-95.

Shane, S. (2012). Reflections on the 2010 AMR decade award: delivering on the promise of entrepreneurship as a field of research. Academy of Management Review 37(1), 10-20.

Silva, E., \& Teixeira, A.A.C. (2008). Surveying structural change: seminal contributions and a bibliometric account. Structural Change and Economic Dynamics, 19(4), 273-300.

Silva, S.T., \& Teixeira, A.A.C. (2009). On the divergence of evolutionary research paths in the past fifty years: a comprehensive bibliometric account. Journal of Evolutionary Economics, 19(5), 605-642.

Small, H.G. (1973). Co-citation in the scientific literature: A new measure of the relationship between two documents. Journal of the American Society for Information Science, 24(4), 265-269.

Stewart, A., \& Cotton, J. (2013). Making sense of entrepreneurship journals Journal rankings and policy choices. International Journal of Entrepreneurial Behaviour \& Research. 19 (3), 303-323.

Taylor, R.S. (1986), Value-added processes in information systems, Norwood, NJ: 
Ablex Publishing Corp.

Teixeira, A.A.C. (2011). Mapping the (in)visible college(s) in the field of entrepreneurship, Scientometrics, 89 (1), 1-36.

van Praag, M., \& Versloot, P. (2008). The economic benefits and costs of entrepreneurship: a review of the research. Foundations and Trends ${ }^{\circledR}$ in Entrepreneurship, 4(2), 65-154.

van Raan, A.F.J. (2003). The use of bibliometric analysis in research performance assessment and monitoring of interdisciplinary scientific developments. Technikfolgenabschätzung, Theorie und Praxis, 12(1), 20-29.

Venkataraman, S., Sarasvathy, S.D., Dew, N., \& Forster, W.R. (2012). Reflections on the 2010 AMR decade award: whither the promise? Moving forward with entrepreneurship as a science of the artificial. Academy of Management Review $37(1), 21-33$.

Verspagen, B., \& Werker, C. (2004). Keith Pavitt and the invisible college of the economics of technology and innovation. Research Policy, 33(9), 1419-1431.

Vieira, P.C., \& Teixeira, A.A.C. (2010). Are finance, management, and marketing autonomous fields of scientific research? An analysis based on journal citations. Scientometrics, 85 (3), 627-646.

Vogel, R. (2012). The visible colleges of management and organization studies: a bibliometric analysis of academic journals. Organization Studies 33 (8), 1015-1043.

Watkins, D., \& Reader, D. (2004). Identifying current trends in entrepreneurship research: A new approach" in D.S. Watkins (Eds.), Annual review of progress in entrepreneurship research, Brussels: European Foundation for Management Development, 311-324.

Welter, F. (2011). Contextualizing entrepreneurship - conceptual challenges and ways forward. Entrepreneurship Theory and Practice 35(1), 165-184.

Zuccala, A. (2006). Modeling the Invisible College. Journal of the American Society for Information Science and Technology, 57(2), 152-168. 


\section{Appendix}

Table A1a: Bibliometric studies - Journal analysis

\begin{tabular}{|c|c|c|c|}
\hline \multicolumn{4}{|c|}{ Application Areas - Journal Analysis } \\
\hline $\begin{array}{l}\text { Scientific } \\
\text { Areas }\end{array}$ & Authors (Date) & Main Research Items & Main Results \\
\hline Economics & $\begin{array}{l}\text { Laband and } \\
\text { Pieters (1994) }\end{array}$ & $\begin{array}{l}\text { Objectives: } \\
\text { - Update paper by Liebowitz and } \\
\text { Palmer (1984 } \\
\text { - Research possible changes in } \\
\text { the economics journal market, } \\
\text { during } 1970-1990 \\
\text { Bibliometric Indicators : } \\
\text { - Number of citations } \\
\text { - Number of citations per article } \\
\text { - Number of articles } \\
\text { - Distribution of citations, via } \\
\text { Lorenz-curve analysis }\end{array}$ & $\begin{array}{l}\text { - Steady decrease in concentration } \\
\text { of citations among the top } \\
\text { economics journals between } \\
1965-1990 \\
\text { - Market share has been taken by } \\
\text { new entrants, but inequality in } \\
\text { distribution of citations remained } \\
\text { stable from } 1970 \text { to } 1990 \\
\text { - Decline in the influence of } \\
\text { "second-tier" general-interest } \\
\text { journals in contrast with the } \\
\text { increasing influence of } \\
\text { specialized journals }\end{array}$ \\
\hline Management & $\begin{array}{l}\text { Phelan et al. } \\
(2002)\end{array}$ & $\begin{array}{l}\text { Objectives: } \\
\text { - Examine internal changes in } \\
\text { content of the Strategic } \\
\text { Management Journal, over } \\
\text { time } \\
\text { Bibliometric Indicators: } \\
\text { - Number of citations } \\
\text { - Number of citations per article } \\
\text { - Number of articles }\end{array}$ & $\begin{array}{l}\text { - Increase in the length of articles, } \\
\text { number of references per article } \\
\text { and number of authors } \\
\text { - Publication lag has increased } \\
\text { - More intra-journal citations } \\
\text { - Proportion of North American } \\
\text { authors remains constant but } \\
\text { there are signs of greater } \\
\text { international collaboration } \\
\text { - Increase in empirical papers }\end{array}$ \\
\hline Marketing & $\begin{array}{l}\text { Baumgartner and } \\
\text { Pieters (2003) }\end{array}$ & $\begin{array}{l}\text { Objectives: } \\
\text { - Explore the overall and } \\
\text { sub-area influence of } \\
\text { marketing journals at three } \\
\text { points in time: } 1996-97, \\
1981-82 \text { and 1966- } 67 \\
\text { Bibliometric Indicators: } \\
\text { - Number of citations } \\
\text { - Number of citations per article } \\
\text { - Number of articles } \\
\text { - Index of structural influence } \\
\text { - Journal impact factor }\end{array}$ & $\begin{array}{l}\text { - Influence share of general } \\
\text { business and managerially } \\
\text { oriented journals has declined in } \\
\text { contrast with the increase in the } \\
\text { influence of specialized marketing } \\
\text { journals } \\
\text { - Select set of journals concentrate } \\
\text { influence in marketing and their } \\
\text { position remained stable over the } \\
\text { studied period } \\
\text { - Journal of Marketing is } \\
\text { considered the most influential } \\
\text { marketing journal }\end{array}$ \\
\hline Accounting & $\begin{array}{l}\text { Van } \\
\text { Campenhout et } \\
\text { al. (2008) }\end{array}$ & $\begin{array}{l}\text { Objectives: } \\
\text { - Compare the overall and } \\
\text { sub-area journal influence in } \\
\text { accounting } \\
\text { Bibliometric Indicators: } \\
\text { - Number of citations } \\
\text { - Number of articles } \\
\text { - Index of structural influence }\end{array}$ & $\begin{array}{l}\text { - Substantial differences exist } \\
\text { between overall and sub-areas } \\
\text { journal influences } \\
\text { - For some sub-areas in } \\
\text { accounting, specialized journals } \\
\text { are not the ones with the highest } \\
\text { influence }\end{array}$ \\
\hline $\begin{array}{l}\text { Entrepreneurs } \\
\text { hip }\end{array}$ & $\begin{array}{l}\text { Gamboa and } \\
\text { Brouthers (2008) }\end{array}$ & $\begin{array}{l}\text { Objectives: } \\
\text { - Discover role of international } \\
\text { entrepreneurship research in } \\
\text { major entrepreneurship, } \\
\text { international business and } \\
\text { management journals } \\
\text { - Assess possible differences in } \\
\text { the type of international } \\
\text { entrepreneurship articles } \\
\text { published in the three type of }\end{array}$ & $\begin{array}{l}\text { - Substantial increase in } \\
\text { international entrepreneurship } \\
\text { content in the top } \\
\text { entrepreneurship journals by } \\
\text { contrast to a much more modest } \\
\text { increase in the top international } \\
\text { business journals and } \\
\text { management journals } \\
\text { - Entrepreneurship journals tend to } \\
\text { favour replication studies while }\end{array}$ \\
\hline
\end{tabular}




\begin{tabular}{lll} 
& \multicolumn{1}{c}{ journals } & \multicolumn{1}{c}{ international business and } \\
& Bibliometric Indicators: & management journals prefer \\
& - Number of articles & nonreplications \\
& - Number and percentage of & \\
international studies & \\
\hline Romano and & Objectives: & - Increasing level of impact in more \\
Ratnatunga & - Assess the impact of small & recent years of the source journal \\
(1996) & enterprise journals and articles & articles as group on \\
& during the 1986-1992 period & contemporary small enterprise \\
& Bibliometric Indicators: & research \\
& - Number of citations & - Substantial number of articles \\
& - Number of articles & were never cited \\
- Average number of citations & - Self-citation problem was seen to \\
& per article & be of limited impact \\
- Average citation rate per & - Entrepreneurship Theory and \\
published article & Practice and Journal of Business \\
- Self citedness; Uncitedness & Venturing were the more \\
- Citation frequency & influential journals during the \\
- Journal impact factor & studied period \\
\hline
\end{tabular}

Table A1b: Bibliometric studies - Themes categorizations

\begin{tabular}{|c|c|c|c|}
\hline \multicolumn{4}{|c|}{ Application Areas - Journal Analysis } \\
\hline $\begin{array}{l}\text { Scientific } \\
\text { Areas }\end{array}$ & Authors (Date) & Main Research Items & Main Results \\
\hline $\begin{array}{l}\text { Structural } \\
\text { Change }\end{array}$ & $\begin{array}{l}\text { Silva and } \\
\text { Teixeira (2008) }\end{array}$ & $\begin{array}{l}\text { Objectives: } \\
\text { - Provide a comprehensive } \\
\text { survey of the economic } \\
\text { literature on structural change } \\
\text { Bibliometric Indicators: } \\
\text { - Number of citations; Number of } \\
\text { articles } \\
\text { - Co-authoring; Abstracts } \\
\text { analysis; Keyword analysis }\end{array}$ & $\begin{array}{l}\text { - Technological issues increased } \\
\text { there relevance during the studied } \\
\text { period } \\
\text { - Recent trends reflect a rising } \\
\text { interest towards empirical work, } \\
\text { despite the increased relevance of } \\
\text { formal work in the nineties }\end{array}$ \\
\hline $\begin{array}{l}\text { Evolutionary } \\
\text { Economics }\end{array}$ & $\begin{array}{l}\text { Silva and } \\
\text { Teixeira (2009) }\end{array}$ & $\begin{array}{l}\text { Objectives: } \\
\text { - Explore main research paths } \\
\text { and contributions in the field of } \\
\text { evolutionary economics } \\
\text { Bibliometric Indicators: } \\
\text { - Number of citations; Number of } \\
\text { articles; Abstracts analysis; } \\
\text { Keyword analysis }\end{array}$ & $\begin{array}{l}\text { - Evolutionary contributions do not } \\
\text { converge to an integrated } \\
\text { approach } \\
\text { - Appearance of two extreme } \\
\text { strands: "History of Economic } \\
\text { Thought and Methodology" and } \\
\text { "Games" } \\
\text { - Increase of formal approaches in } \\
\text { contrast with the stagnation of } \\
\text { empirical work }\end{array}$ \\
\hline $\begin{array}{l}\text { Regional } \\
\text { studies }\end{array}$ & $\begin{array}{l}\text { Cruz and } \\
\text { Teixeira } \\
\text { (Forthcoming) }\end{array}$ & $\begin{array}{l}\text { Objectives: } \\
\text { - Provide evidence that } \\
\text { empirically complements the } \\
\text { qualitative surveys of } \\
\text { cluster-related literature } \\
\text { Bibliometric Indicators: } \\
\text { - Number of citations; Number of } \\
\text { articles; Co-authoring } \\
\text { - Abstracts analysis }\end{array}$ & $\begin{array}{l}\text { - Share of "Appreciative+Empirical" } \\
\text { and "Formal+Empirical" articles } \\
\text { published in the top ranked } \\
\text { cluster-related journals are above } \\
\text { average } \\
\text { - Evidence of positive correlation } \\
\text { between the "quality" of the } \\
\text { journals and formal-related } \\
\text { research }\end{array}$ \\
\hline $\begin{array}{l}\text { Entrepreneurs } \\
\text { hip }\end{array}$ & $\begin{array}{l}\text { Van Praag and } \\
\text { Versloot (2008) }\end{array}$ & $\begin{array}{l}\text { Objectives: } \\
\text { - Assess the contribution of } \\
\text { entrepreneurs to the economy } \\
\text { comparatively to } \\
\text { non-entrepreneurs } \\
\text { Bibliometric Indicators. } \\
\text { - Keyword analysis } \\
\text { - Title, abstract and full-text } \\
\text { analysis }\end{array}$ & $\begin{array}{l}\text { - Entrepreneurs have a higher, but } \\
\text { more volatile, contribution to } \\
\text { employment generation. They pay } \\
\text { lower wages, but their employees } \\
\text { appear to be more satisfied } \\
\text { - Entrepreneurs contribute with } \\
\text { equal importance to innovation but } \\
\text { through different aspects } \\
\text { - Entrepreneurs do not have higher }\end{array}$ \\
\hline
\end{tabular}




\begin{tabular}{|c|c|c|}
\hline & & $\begin{array}{l}\text { productivity levels than their } \\
\text { counterparts. They contribute more } \\
\text { than their counterparts to growth of } \\
\text { value added and productivity } \\
\text { - Despite having lower and riskier } \\
\text { incomes, entrepreneurs are more } \\
\text { satisfied }\end{array}$ \\
\hline $\begin{array}{l}\text { Watkins and } \\
\text { Reader (2004) }\end{array}$ & $\begin{array}{l}\text { Objectives: } \\
\text { - Identify current trends in } \\
\text { entrepreneurship research, in } \\
2000 \text { and } 2001 \\
\text { Bibliometric Indicators: } \\
\text { - Textual analysis (keyword and } \\
\text { abstract analysis); } \\
\text { Co-occurrence matrix }\end{array}$ & $\begin{array}{l}\text { - Identification of twenty-two clusters } \\
\text { - Incidence of work in areas very } \\
\text { attended in the past or in vogue } \\
\text { in the present, such as, } \\
\text { respectively, Entrepreneurial } \\
\text { Psychology and Social } \\
\text { Entrepreneurs or Networking } \\
\text { among Female Entrepreneurs was } \\
\text { lower than expected }\end{array}$ \\
\hline $\begin{array}{l}\text { Ratnatunga and } \\
\text { Romano (1997) }\end{array}$ & $\begin{array}{l}\text { Objectives: } \\
\text { - Analyze, with a quantitative and } \\
\text { qualitative approach, the } \\
\text { articles in contemporary small } \\
\text { enterprise research } \\
\text { Bibliometric Indicators: } \\
\text { - Number of citations; Number of } \\
\text { articles } \\
\text { - Articles full-text analysis }\end{array}$ & $\begin{array}{l}\text { - Increase percentage of most-cited } \\
\text { articles, published by the source } \\
\text { journals } \\
\text { - Substantial percentage of articles } \\
\text { (more than } 50 \% \text { ) are } \\
\text { well-grounded in observational and } \\
\text { contemplative theory } \\
\text { - Diversity of topic areas, empirical } \\
\text { support that there is no coherent } \\
\text { structure for research in the field }\end{array}$ \\
\hline
\end{tabular}

Table A1c: Bibliometric studies - Research Intellectual Structures

\begin{tabular}{|c|c|c|c|}
\hline $\begin{array}{l}\text { Scientific } \\
\text { Areas }\end{array}$ & Authors (Date) & Main Research Items & Main Results \\
\hline Innovation & $\begin{array}{l}\text { Cottrill et al. } \\
\text { (1989) }\end{array}$ & $\begin{array}{l}\text { Objectives: } \\
\text { - Explore the interrelationships } \\
\text { between the specialties of the } \\
\text { diffusion of innovations and } \\
\text { technology transfer, in the } \\
\text { 1966-1972 period } \\
\text { Bibliometric Indicators: } \\
\text { - Number of citations; Number of } \\
\text { articles; Co-citation analysis; } \\
\text { Cluster and factor analysis; } \\
\text { Multidimensional scaling }\end{array}$ & $\begin{array}{l}\text { - Clusters of authors obtained are } \\
\text { similar to those identified in major } \\
\text { reviews of innovation literature } \\
\text { Little cross-referencing between the } \\
\text { authors of diffusion of innovations } \\
\text { and technology transfer } \\
\text { Technology transfer research } \\
\text { tradition is less integrated than the } \\
\text { diffusion of innovations tradition }\end{array}$ \\
\hline $\begin{array}{l}\text { Strategic } \\
\text { Management }\end{array}$ & $\begin{array}{l}\text { Nerur et al. } \\
(2008)\end{array}$ & $\begin{array}{l}\text { Objectives: } \\
\text { - Trace the evolution of the } \\
\text { intellectual structure of the } \\
\text { strategic management field } \\
\text { during the period 1980-2000 } \\
\text { Bibliometric Indicators: } \\
\text { - Number of citations; Number of } \\
\text { articles; Co-citation analysis; } \\
\text { Multidimensional scaling; } \\
\text { Factor analysis; Pathfinder } \\
\text { analysis }\end{array}$ & $\begin{array}{l}\text { - Multidisciplinary origins of strategy } \\
\text { - Large number of significant } \\
\text { inter-correlation between factors } \\
\text { suggests that the field did not } \\
\text { become fragmented } \\
\text { - Theories of the firm have become } \\
\text { central to strategy research, which } \\
\text { suggests a greater theoretical } \\
\text { orientation }\end{array}$ \\
\hline $\begin{array}{l}\text { Management } \\
\text { Information } \\
\text { Systems }\end{array}$ & Culnan (1987) & $\begin{array}{l}\text { Objectives: } \\
\text { - Document the intellectual } \\
\text { structure of Management } \\
\text { Information Systems, from } \\
1980 \text { to } 1985 \\
\text { Bibliometric Indicators: } \\
\text { - Number of citations; Number of } \\
\text { articles; Co-citation analysis }\end{array}$ & $\begin{array}{l}\text { - Identification of five clusters: } \\
\text { foundations; psychological } \\
\text { approaches to MIS design and } \\
\text { use; MIS management; } \\
\text { organizational approaches to MIS } \\
\text { design and use; and curriculum }\end{array}$ \\
\hline
\end{tabular}




\begin{tabular}{|c|c|c|c|}
\hline & & $\begin{array}{l}\text { the development of } \\
\text { eneurship with respect } \\
\text { esearch forefront and } \\
\text { dge base, during the } \\
\text { of 1986-1990, } \\
997 \text { and 2000-2004 } \\
\text { ic Indicators: } \\
\text { of citations; Number of } \\
\text { Co-citation analysis; } \\
\text { analysis }\end{array}$ & $\begin{array}{l}\text { - Entrepreneurship research has } \\
\text { been increasingly self-reflective } \\
\text { - The number and influence of } \\
\text { outsiders has decreased steadily } \\
\text { over time while the reliance on } \\
\text { insiders is greater } \\
\text { - Theoretical issues are more } \\
\text { pervasive } \\
\text { - Research interests have evolved, } \\
\text { despite their consistency } \\
\text { - Researchers have increasingly } \\
\text { specialized thematically }\end{array}$ \\
\hline & $\begin{array}{l}\text { Entrepreneurs Cornelius et al. } \\
\text { ip } \\
(2006) \\
\text { Grégoire et al. } \\
\text { (2006) }\end{array}$ & $\begin{array}{l}\text { Objectives: } \\
\text { - Assess conceptual } \\
\text { convergence in the } \\
\text { entrepreneurship field, through } \\
\text { network co-citation analysis } \\
\text { Bibliometric Indicators: } \\
\text { - Number of citations; Number of } \\
\text { articles; Co-citation analysis; } \\
\text { Cluster analysis }\end{array}$ & $\begin{array}{l}\text { - Evidence of convergence in } \\
\text { entrepreneurship research over } \\
\text { the last twenty-five years } \\
\text { - Levels of convergence } \\
\text { comparatively low } \\
\text { - Entrepreneurship research based } \\
\text { on the contributions of other } \\
\text { disciplines, but evidence indicates } \\
\text { that the field relies increasingly on } \\
\text { its own literature }\end{array}$ \\
\hline & $\begin{array}{l}\text { Schildt et al. } \\
(2006)\end{array}$ & $\begin{array}{l}\text { Objectives: } \\
\text { - Analyze co-citation patterns of } \\
\text { entrepreneurship-related } \\
\text { articles published, from } 2000 \\
\text { to } 2004 \\
\text { Bibliometric Indicators: } \\
\text { - Number of citations; Number of } \\
\text { articles; Co-citation analysis; } \\
\text { Jaccard index; Cluster } \\
\text { algorithm }\end{array}$ & $\begin{array}{l}\text { - Evidence of fragmentation in } \\
\text { entrepreneurship research } \\
\text { - Research findings appear to be } \\
\text { noncumulative } \\
\text { - Research mostly centred on the } \\
\text { United States, but other countries } \\
\text { contribute significantly } \\
\text { - Signs of isolation among } \\
\text { entrepreneurship scholars }\end{array}$ \\
\hline & $\begin{array}{l}\text { Etemad and Lee } \\
(2003)\end{array}$ & $\begin{array}{l}\text { Objectives: } \\
\text { - Define the knowledge network } \\
\text { associated with the field of } \\
\text { international entrepreneurship, } \\
\text { during the period of } 1992 \text { to } \\
2000 \\
\text { Bibliometric Indicators: } \\
\text { - Number of citations; Number of } \\
\text { publications; Bolean search } \\
\text { progression of keywords; } \\
\text { Co-authoring; Analysis of } \\
\text { authors' affiliations }\end{array}$ & $\begin{array}{l}\text { - Scholarly articles, followed by book } \\
\text { reviews, dominate the document } \\
\text { types } \\
\text { - Upward movement over time in } \\
\text { both the number of articles and } \\
\text { their associated citations } \\
\text { - Mild upward trend in both size of } \\
\text { scholarly teams and theirs } \\
\text { co-authorship, during the period of } \\
\text { 1992-1998 } \\
\text { - Authors affiliated with institutions } \\
\text { located in the US dominate the } \\
\text { distribution, but other country } \\
\text { affiliations are also reported } \\
\text { - Scholarly articles and books } \\
\text { constitute the most important } \\
\text { sources upon which research } \\
\text { relays }\end{array}$ \\
\hline
\end{tabular}

Table A1d. Bibliometric studies - Research Invisible Colleges

\begin{tabular}{|c|c|c|c|}
\hline \multicolumn{4}{|c|}{ Application Areas - Research Invisible Colleges } \\
\hline $\begin{array}{l}\text { Scientific } \\
\text { Areas }\end{array}$ & Authors (Date) & Main Research Items & Main Results \\
\hline $\begin{array}{l}\text { Industrial } \\
\text { Relations \& } \\
\text { Labor }\end{array}$ & $\begin{array}{l}\text { Casey and } \\
\text { McMillan (2008) }\end{array}$ & $\begin{array}{l}\text { Objectives: } \\
\text { - Compare Industrial \& Labor } \\
\text { Relations Review intellectual } \\
\text { bases across three periods: } \\
\text { 1974-1984, 1985-1995 and } \\
\text { 1996-2006 } \\
\text { Bibliometric Indicators: }\end{array}$ & $\begin{array}{l}\text { - The most-cited journals were } \\
\text { economic-oriented during the } \\
\text { studied period } \\
\text { Emergence of the field of human } \\
\text { resources and management in } \\
\text { recent years }\end{array}$ \\
\hline
\end{tabular}




\begin{tabular}{|c|c|c|c|}
\hline & & $\begin{array}{l}\text { - Number of citations; Number of } \\
\text { articles; Co-citation network } \\
\text { analysis }\end{array}$ & \\
\hline & $\begin{array}{l}\text { McMillan and } \\
\text { Casey (2007) }\end{array}$ & $\begin{array}{l}\text { Objectives: } \\
\text { - Uncover British Journal of } \\
\text { Industrial Relations for two } \\
\text { time periods, 1986-1995 and } \\
\text { 1996-2005 } \\
\text { Bibliometric Indicators: } \\
\text { - Number of citations; Number of } \\
\text { articles; Co-citation network } \\
\text { analysis }\end{array}$ & $\begin{array}{l}\text { - Evidence suggests that economics } \\
\text { literature remains important, but } \\
\text { sociological and management } \\
\text { literature has dominated in recent } \\
\text { years } \\
\text { - Regarding authors, Millward's } \\
\text { initial influence has been replaced } \\
\text { by Kelly and Wood } \\
\text { - Possible signs of } \\
\text { internationalization }\end{array}$ \\
\hline Management & McMillan (2008) & $\begin{array}{l}\text { Objectives: } \\
\text { - Examine R\&D Management, in } \\
\text { four time periods, 1986-1990, } \\
\text { 1991-1995, 1996-2000 and } \\
\text { 2001-2005 } \\
\text { Bibliometric Indicators: } \\
\text { - Number of citations; Number of } \\
\text { articles; co-citation network } \\
\text { analysis }\end{array}$ & $\begin{array}{l}\text { - During the two first periods R\&D } \\
\text { Management focuses on more } \\
\text { traditional technology and } \\
\text { innovation management sources, } \\
\text { contrasting with the last two } \\
\text { periods, in which R\&D } \\
\text { Management was based on } \\
\text { journals more detached from the } \\
\text { traditional sources } \\
\text { - Cohen and Levinthal's absorptive } \\
\text { capacity model dominates the final } \\
\text { two periods and possibly } \\
\text { constitutes an emerging base }\end{array}$ \\
\hline $\begin{array}{l}\text { Economics of } \\
\text { Technology } \\
\text { and Innovation }\end{array}$ & $\begin{array}{l}\text { Verspagen and } \\
\text { Werker (2004) }\end{array}$ & $\begin{array}{l}\text { Objectives: } \\
\text { - Identify the role of "intellectual } \\
\text { leaders" in connecting the } \\
\text { research network } \\
\text { - Study the structure of the field } \\
\text { in terms of sub-communities } \\
\text { Bibliometric Indicators: } \\
\text { - Survey analysis }\end{array}$ & $\begin{array}{l}\text { - The network of scholars in the field } \\
\text { may be characterized as a } \\
\text { scale-free network } \\
\text { - The field does not seem to evolve } \\
\text { in a mode of competition between } \\
\text { paradigmatic approaches to the } \\
\text { object of study }\end{array}$ \\
\hline $\begin{array}{l}\text { Entrepreneurs } \\
\text { hip }\end{array}$ & $\begin{array}{l}\text { Reader and } \\
\text { Watkins (2006) }\end{array}$ & $\begin{array}{l}\text { Objectives: } \\
\text { - Identify groups of } \\
\text { entrepreneurship authors } \\
\text { whose work falls into similar } \\
\text { areas and explore the themes } \\
\text { that characterize } \\
\text { entrepreneurship field } \\
\text { - Investigate the social and } \\
\text { collaborative structure of } \\
\text { entrepreneurship research } \\
\text { Bibliometric Indicators: } \\
\text { - Number of citations; Number of } \\
\text { articles; Co-citation analysis; } \\
\text { Cluster analysis; Correlation } \\
\text { matrix; Factor analysis; } \\
\text { Questionnaire survey }\end{array}$ & $\begin{array}{l}\text { - Findings reveal nine clusters of } \\
\text { authors whose work falls into } \\
\text { similar areas } \\
\text { - Little evidence of international } \\
\text { sharing of ideas } \\
\text { - Strong evidence that closely } \\
\text { related authors share both formal } \\
\text { and informal communication links }\end{array}$ \\
\hline
\end{tabular}


Table A2. John Carroll University Classification of entrepreneurship journals

\section{Level I}

1. Journal of Business Venturing

2. Small Business Economics

3. Entrepreneurship: Theory \& Practice

4. Journal of Small Business Management

\section{Level II}

1. Entrepreneurship, Innovation and Change

2. Family Business Review

3. International Journal of Entrepreneurship Development, Education and Training

4. International Journal of Entrepreneurship

5. International Journal of Technological Innovation and Entrepreneurship

6. Journal of Developmental Entrepreneurship

7. Journal of Enterprising Culture

8. Journal of Entrepreneurship Education

9. Journal of Private Enterprise

10. New England Journal of Entrepreneurship

11. Small Business and Enterprise Development

\section{Level III}

1. Economic Analysis: A Journal of Enterprise and Participation

2. Enterprise and Innovation Management Studies

3. Entrepreneurship Development Review

4. Journal of Entrepreneurship

5. Journal of International Business and Entrepreneurship

6. Journal of Technology Transfer

7. Small Enterprise Research: The Journal of SEAANZ

8. Studies in Cultures, Organizations and Societies

Source: Katz, J. and Boal, K. (2002), "Entrepreneurship Journal Rankings", in http://www.marketingtechie.com/articles/mtart20020307.pdf, accessed on July 2009. 
Table A3: Information on current and previous professional affiliations/ visiting academic institutions of top authors

\begin{tabular}{|c|c|c|c|}
\hline & Author & Affiliations/ Visiting Academic Institutions ${ }^{\text {a }}$ & Previous Affiliations/ Visiting Academic Institutions ${ }^{\text {b }}$ \\
\hline \multirow{7}{*}{1} & \multirow{7}{*}{ Audretsch, D. } & Indiana University, US & Georgia State University, US \\
\hline & & Ewing Marion Kauffman Foundation, US & Middlebury College, US \\
\hline & & Friedrich-Schiller-University Jena, DE & Social Science Centre Berlin, DE \\
\hline & & ZEW, Centre for Economic Research, DE & University of Durham, UK \\
\hline & & $\begin{array}{l}\text { CEPR, Centre for Economic Policy Research, } \\
\text { UK }\end{array}$ & Kiel Institute of World Economics, DE \\
\hline & & EIM Consulting for Small and Medium-Sized & \\
\hline & & Business, NL & Tinbergen Institute, NL \\
\hline \multirow{9}{*}{2} & \multirow{9}{*}{ Acs, Z. } & Max Planck Institute of Economics, DE & University of Maryland, US \\
\hline & & University of Baltimore, US & Social Science Centre Berlin, DE \\
\hline & & Ewing Marion Kauffman Foundation, US & University of Illinois Springfield, US \\
\hline & & - & Manhattan College, US \\
\hline & & - & Columbia University, US \\
\hline & & - & Middlebury College, US \\
\hline & & - & Santa Anna School of Advanced International Studies, IT \\
\hline & & - & Université Aix-Marseille II, FR \\
\hline & & - & University of St Andrews, UK \\
\hline \multirow{4}{*}{3} & \multirow{4}{*}{ Cooper, A. } & Harvard University, US & Stanford University, US \\
\hline & & - & University of Pennsylvania, US \\
\hline & & - & University of Manchester, UK \\
\hline & & - & International Institute for Management Development, $\mathrm{CH}$ \\
\hline \multirow{13}{*}{4} & \multirow{13}{*}{ Aldrich, $\mathrm{H}$. } & - & Cornell University, US \\
\hline & & - & Stanford University, US \\
\hline & & - & International Institute of Management, DE \\
\hline & & - & University of Oxford, UK \\
\hline & & - & Centre for Environmental Studies, UK \\
\hline & & - & Universita' Commerciale Luigi Bocconi, IT \\
\hline & & - & Wirtschaftsuniversität Wien, $\mathrm{AT}$ \\
\hline & & - & BI Norwegian School of Management, NO \\
\hline & & - & Universita' degli Studi di Trento, IT \\
\hline & & - & University of British Columbia, CA \\
\hline & & - & Keio University, JP \\
\hline & & - & Jönköping University, SE \\
\hline & & - & Universitat Autònoma de Barcelona, ES \\
\hline \multirow{7}{*}{5} & \multirow{7}{*}{ Reynolds, P. } & - & Florida International University, US \\
\hline & & - & University of London, UK \\
\hline & & - & Babson College, US \\
\hline & & - & Marquette University, US \\
\hline & & - & University of Minnesota, US \\
\hline & & - & University of Pennsylvania, US \\
\hline & & - & $\begin{array}{l}\text { INSEAD, European Institute of Business Administration, } \\
\text { FR }\end{array}$ \\
\hline \multirow{3}{*}{6} & \multirow{3}{*}{ Gartner, W. } & - & University of Southern California, US \\
\hline & & - & San Francisco State University, US \\
\hline & & - & Georgetown University, US \\
\hline \multirow{2}{*}{7} & \multirow{2}{*}{ Zahra, S. } & - & Babson College, US \\
\hline & & - & Georgia State University, US \\
\hline 8 & Porter, M. & - & - \\
\hline \multirow{2}{*}{9} & \multirow{2}{*}{ MacMillan, I. } & - & New York University, US \\
\hline & & - & Columbia University, US \\
\hline \multirow{3}{*}{10} & \multirow{3}{*}{ Storey, D. } & University of Reading, UK & - \\
\hline & & University of Manchester, UK & - \\
\hline & & University of Durham, UK & - \\
\hline 11 & Schumpeter, J. † & 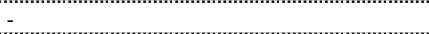 & - \\
\hline \multirow{2}{*}{12} & \multirow{2}{*}{ Miller, D. } & - & McGill University, CA \\
\hline & & - & Columbia University, US \\
\hline
\end{tabular}




\begin{tabular}{|c|c|c|c|}
\hline & Author & iliations/ Visiting Academic Institutiol & Previous Affiliations/ Visiting Academic Institutions ${ }^{b}$ \\
\hline \multirow{5}{*}{13} & \multirow{5}{*}{ Shane, S. } & - & Imperial College London, UK \\
\hline & & - & University of Maryland, US \\
\hline & & - & National University of Singapore, SG \\
\hline & & - & Massachusetts Institute of Technology, US \\
\hline & & - & Georgia Institute of Technology, US \\
\hline \multirow{3}{*}{14} & \multirow{3}{*}{ Evans, D. } & University of London, UK & Fordham University, US \\
\hline & & - & Social Science Centre Berlin, DE \\
\hline & &.- & New York University, US \\
\hline \multirow{6}{*}{15} & \multirow{6}{*}{ Bygrave, W. } & University of London, UK & University of Nottingham, UK \\
\hline & & & INSEAD, European Institute of Business \\
\hline & & - & Administration, FR \\
\hline & & & Bryant University, US \\
\hline & & - & Boston University, US \\
\hline & & - & University of Massachusetts Dartmouth, US \\
\hline 16 & Birley, S. & - & Imperial College London, UK \\
\hline 17 & Covin, J. & - & Georgia Institute of Technology, US \\
\hline \multirow{3}{*}{18} & \multirow{3}{*}{ Wright, M. } & Erasmus University Rotterdam, NL & EMLYON Business School, FR \\
\hline & & $\begin{array}{l}\text { INSEAD, European Institute of } \\
\text { Business Administration, FR }\end{array}$ & University of Ghent, BE \\
\hline & & University of Siena, IT & -... \\
\hline \multirow{2}{*}{19} & \multirow{2}{*}{ Brush, C. } & $\begin{array}{l}\text { Norwegian University of Science and } \\
\text { Technology, NO }\end{array}$ & Boston University, US \\
\hline & & - & Jönköping University, SE \\
\hline \multirow{5}{*}{20} & \multirow{5}{*}{ Westhead, P. } & Bodø University College, NO & \\
\hline & & & University of Warwick, UK \\
\hline & & - & University of Stirling, UK \\
\hline & & - & University of Nottingham, UK \\
\hline & & - & Imperial College London, UK \\
\hline 21 & Hambrick, D. & $\begin{array}{cc}\cdots \\
--\end{array}$ & - \\
\hline \multirow{8}{*}{22} & \multirow{8}{*}{ Williamson, $\mathrm{O}$. } & - & Australian National University, AU \\
\hline & & - & Panthéon-Sorbonne University, FR \\
\hline & & - & Northwestern University, US \\
\hline & & - & Saarland University, DE \\
\hline & & - & Indiana University, US \\
\hline & & - & Harvard University, US \\
\hline & & - & University of Kyoto, JP \\
\hline & & - & University of Warwick, UK \\
\hline \multirow{3}{*}{23} & \multirow{3}{*}{ Vesper, K. } & - & Baylor University, US \\
\hline & & - & Babson College, US \\
\hline & & - & University of Calgary, CA \\
\hline 24 & Eisenhardt, K. & - & - \\
\hline 25 & Hisrich, R. & - & Case Western Reserve University, US \\
\hline 26 & Sexton, D. &.- & Baylor University, US \\
\hline \multirow{2}{*}{27} & \multirow{2}{*}{ Van de Ven, A. } & - & University of Pennsylvania, US \\
\hline & & - & Kent State University, US \\
\hline \multirow{3}{*}{28} & \multirow{3}{*}{ Timmons, J. $\dagger$} & - & Northeastern University, US \\
\hline & & - & Boston College, US \\
\hline & & - & Colgate University, US \\
\hline 29 & Sapienza, H. & - & University of South Carolina, US \\
\hline
\end{tabular}




\begin{tabular}{|c|c|c|c|}
\hline & Author & Affiliations/ Visiting Academic Institutions ${ }^{\text {a }}$ & Previous Affiliations/ Visiting Academic Institutions ${ }^{b}$ \\
\hline \multirow{5}{*}{30} & \multirow{5}{*}{ Bates, $\mathrm{T}$. } & - & New School, US \\
\hline & & - & University of Vermont, US \\
\hline & & - & University of North Carolina, US \\
\hline & & - & University of California, Berkeley, US \\
\hline & & - & University of California, Los Angeles, US \\
\hline \multirow{3}{*}{31} & \multirow{3}{*}{ Brockhaus, R. } & - & Kansas State University, US \\
\hline & & - & University of Waikato, NZ \\
\hline & & - & Baylor University, US \\
\hline 32 & Hitt, M. & 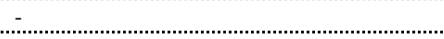 & Arizona State University, US \\
\hline \multirow{4}{*}{33} & \multirow{4}{*}{ Chrisman, J. } & University of Alberta, CA & University of Calgary, CA \\
\hline & & - & Louisiana State University, US \\
\hline & & - & University of South Carolina, US \\
\hline & & - & University of Kentucky, US \\
\hline \multirow{4}{*}{34} & \multirow{4}{*}{ Dess, G. } & - & Chinese University of Hong Kong, CN \\
\hline & & - & BI Norwegian School of Management, NO \\
\hline & & - & Dartmouth College, US \\
\hline & & $\therefore$ & University of Oporto, PT \\
\hline 35 & Baumol, W. & Princeton University, US & - \\
\hline \multirow{2}{*}{36} & \multirow{2}{*}{ Kanter, R. } & - & Yale University, US \\
\hline & & - & Brandeis University, US \\
\hline \multirow{2}{*}{37} & \multirow{2}{*}{ Cohen, W. } & - & Carnegie Mellon University, US \\
\hline & & - & Harvard University, US \\
\hline \multirow{3}{*}{38} & \multirow{3}{*}{ Blanchflower, D. } & University of Munich, DE & University of Surrey, UK \\
\hline & & University of Bonn, GE & - \\
\hline & & University of Stirling, UK &..- \\
\hline 39 & Caves, R. & - & Harvard University, US \\
\hline 40 & Geroski, P. $\dagger$ & $\begin{array}{cc}- \\
\cdots\end{array}$ & - \\
\hline 41 & Jovanovic, B. & -... & University of Pennsylvania, US \\
\hline \multirow{2}{*}{42} & \multirow{2}{*}{ Cressy, R. } & - & University of Warwick, UK \\
\hline & & - & University of Hull, UK \\
\hline \multirow{4}{*}{43} & \multirow{4}{*}{ Scherer, F. } & - & Princeton University, US \\
\hline & & - & Swarthmore College, US \\
\hline & & - & Northwestern University, US \\
\hline & & - & International Institute of Management, DE \\
\hline 44 & Dunne, T. & - & University of Oklahoma, US \\
\hline \multirow{3}{*}{45} & \multirow{3}{*}{ Berger, A. } & University of Pennsylvania, US & - \\
\hline & & Tilburg University, NL & - \\
\hline & & - & Georgetown University, US \\
\hline \multirow[b]{2}{*}{46} & \multirow[b]{2}{*}{ Wagner, J. } & Max Planck Institute of Economics, DE & - \\
\hline & & $\begin{array}{l}\text { IZA Institute for the Study of Labor, DE } \\
\text { ZBW, German National Library of Economics, } \\
\text { DE }\end{array}$ & - \\
\hline \multirow{2}{*}{47} & \multirow{2}{*}{ Davis, $\mathrm{S}$. } & - & Massachusetts Institute of Technology, US \\
\hline & & - & University of Maryland, US \\
\hline
\end{tabular}

Source: Authors' personal web pages and universities web pages.

Note: Due to the absence of information, we have not identified the current visiting institutions or last affiliation of 6 authors.

${ }^{a}$ Validity guaranteed until August 2009.

${ }^{\mathrm{b}}$ Last affiliation(s) post-doctoral program. 